

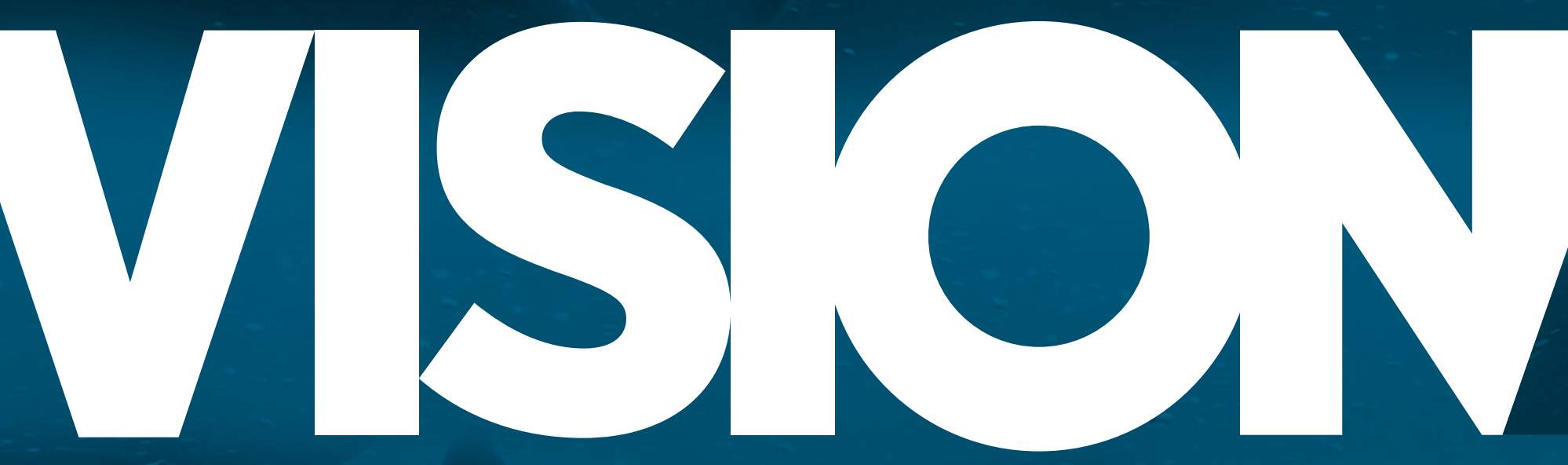


Man did not weave the

web of life, he is merely

a strand in it. Whatever

he does to the web, he

does to himself. All things

share the same breath-

the beast, the tree, the

man... the air shares its

spirit with all the life it

supports. Take only

memories, leave nothing

but footprints.

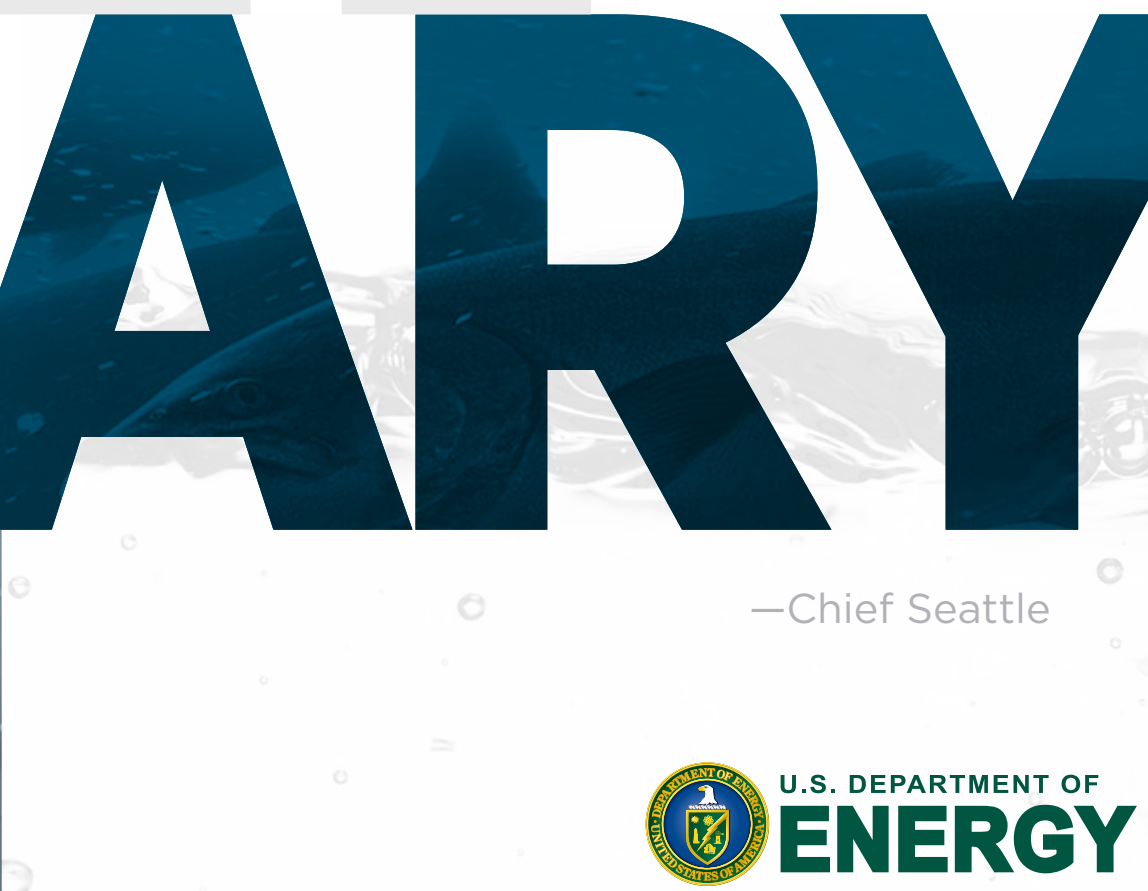


$\mathrm{MCN}$

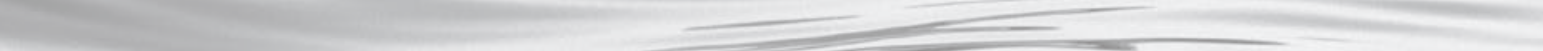
Lis

\section{FROM THE DIRECTOR}

\section{$\sum=$}


America's first renewable electricity source, hydropower, has been providing flexible, low-cost, and low-emission renewable energy for more than 100 years. In addition to producing electricity, many of today's hydropower facilities provide flood control, irrigation, water supply, and recreational opportunities. Hydropower deployment also delivers public health and environmental benefits-reduced greenhouse gas emissions, reduced air pollutant emissions, and reduced water consumption-and is facilitating the integration of increased levels of variable generation, such as wind and solar in various regions of our country.

The Hydropower Vision looks toward the future of the nation's hydropower sector, highlighting how hydropower can continue to be a substantial part

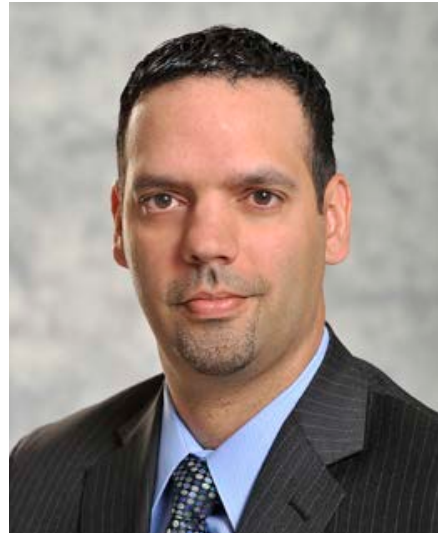
of meeting the challenge to produce clean, affordable, and secure energy in the 21st century. With a goal of developing a cohesive long-term future for the benefit of the entire U.S. hydropower community, this landmark report analyzes a range of growth scenarios and establishes an objective roadmap of actions the hydropower industry, research community, and others can take to achieve higher levels of hydropower deployment within a sustainable national energy mix.

The Hydropower Vision represents a significant and extensive collaboration of the Energy Department, and experts from more than 150 organizations-including equipment industry associations; manufacturers; environmental organizations; federal, state, and local government agencies; utilities; developers; independent power producers; research institutions and laboratories; and more. To the more than 300 diverse individuals who supported this massive effort with their time and expertise, I express my sincerest gratitude. Their work helped ensure that the Hydropower Vision achieves not only breadth, but also depth in its approach to defining the future of this vital renewable energy resource.

The Hydropower Vision highlights the great potential of untapped hydropower resources across the United States, finding that U.S. hydropower could grow from 101 gigawatts (GW) of combined generating and storage capacity to nearly $150 \mathrm{GW}$ by 2050 -with more than $50 \%$ of this growth realized by 2030 . Growth under this scenario would result from a combination of $13 \mathrm{GW}$ of new hydropower generation capacity (upgrades to existing plants, adding power at existing dams and canals, and limited development of new stream-reaches), and 36 GW of new pumped storage capacity. Between 2017 and 2050, hydropower could save $\$ 209$ billion in avoided damages from greenhouse gas emissions, $\$ 58$ billion from avoided healthcare costs and economic damages due to air pollution, and 30 trillion gallons of water, equivalent to roughly 45 million Olympic-size swimming pools.

The factors that led to the hydropower industry's historical growth over the past century are different than the opportunities and challenges facing the industry today. Continued evolution, including transformative technical innovations able to meet the co-objectives of environmental sustainability and low-carbon energy, will be critical to enabling hydropower growth. The Hydropower Vision will help the nation usher in a new era for hydropower-one that ensures that America's first renewable electricity source maintains its place in our nation's 21st-century energy system.

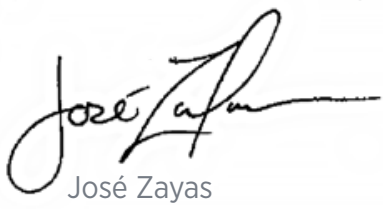

Director, Wind and Water Power Technologies Office

U.S. Department of Energy 


\section{Acronyms}

\begin{tabular}{|c|c|}
\hline AP2 & Air Pollution Emissions Experiments and Policy Analysis Model (formerly APEEP) \\
\hline BAA & balancing authority area \\
\hline BAU & Business as Usual or Business-as-Usual \\
\hline BPA & Bonneville Power Administration \\
\hline Btu & British thermal unit \\
\hline CAISO & California Independent System Operator \\
\hline $\mathrm{CO}_{2}$ & carbon dioxide \\
\hline CPP & Clean Power Plan (EPA) \\
\hline DOE & U.S. Department of Energy \\
\hline DOI & U.S. Department of the Interior \\
\hline EIA & U.S. Energy Information Administration \\
\hline EPA & U.S. Environmental Protection Agency \\
\hline EROI & energy return on investment \\
\hline FERC & Federal Energy Regulatory Commission \\
\hline FPA & Federal Power Act \\
\hline GDP & gross domestic product \\
\hline GHG & greenhouse gas(es) \\
\hline GW & gigawatt(s) \\
\hline GWh & gigawatt-hour(s) \\
\hline ILP & Integrated Licensing Process (Federal Energy Regulatory Commission) \\
\hline IOU & investor-owned utility \\
\hline IPP & independent power producer \\
\hline ISO & independent system operator \\
\hline ITC & investment tax credit \\
\hline IWG & Interagency Working Group (on Social Cost of Carbon) \\
\hline LIHI & Low Impact Hydropower Institute \\
\hline kW & kilowatt(s) \\
\hline
\end{tabular}




\begin{tabular}{|c|c|}
\hline kWh & kilowatt hour(s) \\
\hline MISO & Midcontinent Independent System Operator \\
\hline MW & megawatt(s) \\
\hline MWh & megawatt-hour(s) \\
\hline NEPA & National Environmental Policy Act \\
\hline NERC & North American Electric Reliability Corporation \\
\hline NG & natural gas $(\mathrm{CH} 4)$ \\
\hline $\mathrm{NO}_{\mathrm{x}}$ & nitrogen oxides \\
\hline NPD & non-powered dams \\
\hline NREL & National Renewable Energy Laboratory \\
\hline NSD & new stream-reach development \\
\hline O\&M & operations and maintenance \\
\hline ORNL & Oak Ridge National Laboratory \\
\hline $\mathrm{PM}_{2.5}$ & Particles less than 2.5 micrometers in diameter, referred to as "fine" particles. \\
\hline PMA & Power Marketing Administration (Federal) \\
\hline PPA & power purchase agreement \\
\hline PSH & pumped storage hydropower \\
\hline PTC & production tax credit \\
\hline PV & photovoltaic (solar) \\
\hline REC & renewable energy credit or renewable energy certificate \\
\hline ReEDS & Regional Energy Deployment System (ReEDS Model) \\
\hline RPS & renewable portfolio standard \\
\hline RTO & regional transmission organization \\
\hline SCC & social cost of carbon \\
\hline $\mathrm{SO}_{2}$ & sulfur dioxide \\
\hline TVA & Tennessee Valley Authority \\
\hline TWh & terawatt-hour(s); trillion $\mathrm{kWh}$ \\
\hline VG & variable generation (or variable generation resources) \\
\hline
\end{tabular}


The U.S. Department of Energy's (DOE's) Wind and Water Power Technologies Office has led a first-ofits-kind comprehensive analysis to evaluate future pathways for low-carbon, renewable hydropower (hydropower generation and pumped storage) in the United States, focused on continued technical evolution, increased energy market value, and environmental sustainability.

Undertaken through a broad-based collaborative effort, the Hydropower Vision initiative had four principal objectives:

- Characterize the current state of hydropower in the United States, including trends, opportunities, and challenges;

- Identify ways for hydropower to maintain and expand its contributions to the electricity and water management needs of the nation from the present through 2030 and 2050;

- Examine critical environmental and social factors to assess how existing hydropower operations and potential new projects can minimize adverse effects, reduce carbon emissions from electricity generation, and contribute to stewardship of waterways and watersheds; and

- Develop a roadmap identifying stakeholder actions that could support responsible ongoing operations and potential expansion of hydropower facilities.

The Hydropower Vision analysis finds that U.S. hydropower could grow from 101 gigawatts (GW) of capacity to nearly $150 \mathrm{GW}$ by 2050 . Growth under this modeled scenario would result from a combination of $13 \mathrm{GW}$ of new hydropower generation capacity (upgrades to existing plants, adding power at existing dams and canals, and limited development of new stream-reaches), and $36 \mathrm{GW}$ of new pumped storage capacity. If this level of growth is achieved, benefits such as a savings of $\$ 209$ billion from avoided greenhouse gas (GHG) emissions could be realized, of which $\$ 185$ billion would be attributable to operation of the existing hydropower fleet. Transformative technical innovations able to meet the co-objectives of environmental sustainability and low-carbon energy will be critical to enabling additional hydropower growth beyond these levels.
The Hydropower Vision report specifically does not evaluate or recommend new policy actions but instead analyzes the feasibility and certain benefits and costs of various credible scenarios, all of which could inform policy decisions at the federal, state, tribal, and local levels.

\section{The Hydropower Vision Framework}

The Hydropower Vision report is based on three equally important foundational principles, or "pillars," arrived at through extensive stakeholder input. These pillars are critical to ensuring the integrity of the research, modeling, and analysis in the Hydropower Vision:

Optimization: Optimize the value and power generation contribution of the existing hydropower fleet within the nation's energy mix to benefit national and regional economies, maintain critical national infrastructure, and improve energy security.

Growth: Explore the feasibility of credible long-term deployment scenarios for responsible growth of hydropower capacity and energy production.

Sustainability: Ensure that hydropower's contributions toward meeting the nation's energy needs are consistent with the objectives of environmental stewardship and water use management.

\section{Hydropower Vision: Responsibly operate, optimize, and develop hydropower in a manner that maximizes opportunities for low-cost, low-carbon renewable energy production, economic stimulation, and environmental stewardship to provide long-term benefits for the nation.}

\section{Hydropower Vision Insights}

Applying these foundational principles to both the quantitative and qualitative analyses in the Hydropower Vision led to several key insights regarding the role of existing and future hydropower in the U.S. power sector:

- Existing hydropower facilities have high value within the U.S. energy sector, providing low-cost, low-carbon, renewable energy as well as flexible grid support services; 
- Hydropower has significant near-term potential to increase its contribution to the nation's clean generation portfolio via economically and environmentally sustainable growth through optimized use of existing infrastructure;

- Meeting the long-term potential for growth at potential sites that are not developed for hydropower is contingent upon continued commitment to innovative technologies and strategies to increase economic competitiveness while meeting the need for environmental sustainability;

- Significant potential exists for new pumped storage hydropower to meet grid flexibility needs and support increased integration of variable generation resources, such as wind and solar;

- The economic and societal benefits of both existing and potential new hydropower, as quantified in this report, are substantial and include job creation, cost savings in avoided mortality and economic damages from air pollutants, and avoided GHG emissions.

\section{Hydropower has provided a cumulative $10 \%$ of U.S. electricity generation over the past 65 years (1950-2015), and $85 \%$ of cumulative U.S. renewable power generation over the same time period.}

\section{Study Summary}

DOE's approach to characterizing key aspects of hydropower and assessing future potential had two major components: data gathering and computational analysis. More than 300 experts from over 150 organizations and agencies participated as task force members and reviewers in documenting the opportunities, challenges, and technical and market aspects of the industry. These experts also contributed cost data and input on methods and assumptions used in the computational analysis.

DOE's national laboratories used national-scale electric sector capacity expansion modeling to simulate the cost of construction and operation of generation and transmission capacity to meet electricity demand and other power system requirements on a competitive basis with other generation sources over discrete study periods-2017, through 2030, and through 2050. These modeling methods were used to evaluate a range of possible future outcomes for hydropower deployment based on resource availability, technical innovation, economic factors, market forces, and potential environmental effects. The modeling analysis assumed policy as legislated as of December 31, 2015, including the U.S. Environmental Protection Agency's Carbon Pollution Standards for Existing Power Plants (Clean Power Plan). ${ }^{01}$

In addition to modeling future outcomes of new deployment, the future contributions of the existing hydropower fleet were evaluated. As of the end of 2015, the U.S. hydropower generation fleet included 2,198 active power plants with a total capacity of $79.6 \mathrm{GW}$ and 42 pumped storage hydropower (PSH) plants totaling 21.6 GW, for a total installed capacity of 101 GW. PSH comprised the majority (97\%) of the utility-scale electricity storage in the United States at the end of 2015.

\section{Analysis Overview}

For the report, four categories of hydropower projects were evaluated:

1. Existing hydropower plants that can be upgraded and optimized for increased generation and environmental performance;

2. New power plants at existing non-powered dams (NPDs) and other water conveyance infrastructures such as irrigation canals;

3. New and existing PSH facilities and upgrades; and

4. New stream-reach development (NSD).

Due to the limits of the quantitative economic modeling framework used, potential capacity additions from canals; from upgrades to existing pumped storage facilities; and in Alaska and Hawaii are only discussed qualitatively throughout the report.

More than 50 hydropower deployment scenarios were modeled to assess the relative influence of specific variables on hydropower growth in the competitive energy marketplace. The factors that exerted the greatest influence on the modeling results were: (1) technology innovation to reduce cost; (2) improvement of market lending conditions by valuing the long asset

01. Though the Supreme Court issued a stay of the Clean Power Plan (CPP) in February 2016, the CPP is treated as law in all scenarios. The CPP is modeled using mass-based goals for all states with national trading of allowances available. Although states can ultimately choose rateor mass-based compliance and will not necessarily trade with all other states, a nationally traded mass-based compliance mechanism is viewed as a reasonable reference case for the purpose of exploring hydropower deployment under a range of electricity system scenarios. 
life of hydropower facilities; and (3) the concurrent influence of several environmental considerations. These factors and others were combined in a final set of four scenarios. This set of scenarios was used to quantify potential long-term hydropower growth and a range of potential benefits from specific metrics, such as GHG reduction, when compared to a baseline scenario representing no new unannounced hydropower development. Growth in hydropower generation capacity in the various scenarios was added to current installed capacity to establish a range of potential total capacity.

\section{Results: Overall Positive Benefit for the Nation}

The Hydropower Vision analysis found that-under a credible modeled scenario in which technology advancement lowers capital and operating costs, innovative market mechanisms increase revenue and lower financing costs, and a combination of environmental considerations are taken into account-U.S. hydropower including PSH could grow from 101 GW of capacity in 2015 to $150 \mathrm{GW}$ by 2050 . Growth potential is tied to a complex set of variables, and changes in these variables over long periods of time are difficult to predict. Modeling results therefore serve primarily as a basis for identifying the key factors and drivers likely to influence future trends and outcomes, and should not be interpreted as DOE projections or targets.
Near-term growth of hydropower generation (through 2030), estimated as $9.4 \mathrm{GW}$ under this scenario, is driven primarily from upgrades of existing hydropower facilities (5.6 GW) and powering non-powered dams (3.6 GW). Long-term growth of 3.4 GW between 2030 and 2050 includes $1.7 \mathrm{GW}$ of NSD, for a total of $12.8 \mathrm{GW}$ of new growth by 2050 . The analysis also concluded that potential exists to increase NSD beyond this level; however, this development is unlikely to occur without significant, transformational innovation in technology and development approaches that can lower costs and meet environmental sustainability requirements.

Under a range of scenarios, PSH can increase in both the near term (to 2030), where $16.2 \mathrm{GW}$ are added, and in the longer term (to 2050), where an additional $19.3 \mathrm{GW}$ are deployed, for a total of $35.5 \mathrm{GW}$ by 2050 . This growth is driven primarily by modeled growth in other variable renewable generation sources, such as wind and solar, and by the inherent flexibility of pumped storage and its ability to provide needed operating reserves and other essential grid reliability services. With increased PSH deployment under Advanced Technology and Low Cost Finance modeling assumptions, PSH provides more operating reserves (52\%) than any other technology by 2050 .

Benefits-Existing and New Capacity, 2017-2050a,b,c

\begin{tabular}{|c|c|c|c|c|c|}
\hline & Economic & $\begin{array}{c}\text { GHG } \\
\text { Greenhouse } \\
\text { Gases }\end{array}$ & $\begin{array}{c}\text { Air } \\
\text { Pollution }\end{array}$ & Water & Jobs \\
\hline $\begin{array}{l}\text { Existing } \\
\text { Fleet } \\
\text { and New } \\
\text { Capacity } \\
\text { Additions } \\
\text { Combined } \\
\text { (149.5 GW) }\end{array}$ & $\begin{array}{l}\$ 148 \text { billion in cu- } \\
\text { mulative economic } \\
\text { investment }^{d} \\
\$ 110 \text { billion for } \\
\text { hydropower gen- } \\
\text { eration and } \$ 38 \\
\text { billion for PSH }\end{array}$ & $\begin{array}{l}\text { Cumulative } \mathrm{GHG} \\
\text { emissions reduced } \\
\text { by } 5,600,000,000 \\
\text { metric tons } \mathrm{CO}_{2}^{-} \\
\text {equivalent, saving } \\
\$ 209 \text { billion in } \\
\text { avoided global } \\
\text { damages }\end{array}$ & $\begin{array}{l}\$ 58 \text { billion savings in avoided } \\
\text { mortality, morbidity, and } \\
\text { economic damages from } \\
\text { cumulative reduction in emis- } \\
\text { sions of } \mathrm{SO}_{2}, \mathrm{NO}_{x} \text {, and } \mathrm{PM}_{2.5} \\
6,700-16,200 \text { premature } \\
\text { deaths avoided }\end{array}$ & $\begin{array}{l}\text { Cumulative } 30 \\
\text { trillion gallons } \\
\text { of water with- } \\
\text { drawals avoided } \\
\text { for the electric } \\
\text { power sector }\end{array}$ & $\begin{array}{l}\text { Over } 195,000 \\
\text { hydropower- } \\
\text { related gross } \\
\text { jobs spread } \\
\text { across the } \\
\text { nation in } 2050\end{array}$ \\
\hline
\end{tabular}

a. Cumulative benefits are reported on a Net Present Value basis (\$2015) for the period of 2017 through 2050.

b. Estimates reported reflect central values within a range of estimates as compared to the baseline scenario with no new hydropower.

c. Existing fleet includes new projects and plant retirements announced as of the end of 2015; new development reflects the modeled scenario titled Advanced Technology, Low Cost Finance, and Combined Environmental Considerations.

d. Capital investment and annual operating expenses, 2017-2050.

Selected benefits and impacts from the existing hydropower fleet and from new deployment, 2017-2050 
The Hydropower Vision modeled capacity of $150 \mathrm{GW}$ by 2050 yields a scenario under which a combined $\$ 209$ billion savings from avoided global damages from GHG emissions is possible, including $\$ 185$ billion in savings from the existing hydropower fleet being operated through 2050 . The figure below provides an itemized quantification of selected benefits realized by both the existing fleet and new growth between 2017 and 2050.

\section{Roadmap for Key Stakeholder Actions}

The Hydropower Vision roadmap outlines potential actions, in a non-prescriptive manner, for consideration by all stakeholder sectors. Within the five topical action areas listed below, 21 sub-categories include 64 actions developed in conjunction with task forces representing a wide range of stakeholder perspectives. The defined roadmap action areas are:

1. Technology Advancement to advance development of innovative technologies and system design concepts needed to reduce costs and improve both power production efficiencies and environmental performance;

2. Sustainable Development and Operation to further integrated approaches that incorporate the principles, metrics, and methodologies required to balance environmental, social, and economic factors;

3. Enhanced Revenue and Market Structures that appropriately compensate and incentivize new and existing hydropower, given the numerous energy production and grid support services it provides;

4. Regulatory Process Optimization by increasing access to shared data, making information on relevant scientific advances available, and furthering other means of enhancing process efficiency and reducing risks and costs; and

\section{Enhanced Collaboration, Education, and Outreach} including dissemination of best practices for maintaining, operating, and constructing facilities; and developing curricula for vocational and university programs to train new hydropower professionals.

\section{Risks of Inaction}

While the hydropower industry is mature in terms of established facilities and technologies, many actions and efforts remain critical to further advancement of U.S. domestic hydropower as a key future energy source. Continued technology development is needed to increase efficiency, improve sustainability, and reduce costs. Improvement in the way markets value grid reliability services, air quality and reduced GHG emissions, and long asset lifetimes can increase revenues.

The lack of well-informed, coordinated actions such as those identified in the roadmap reduces the likelihood that potential benefits to the nation will be realized. Failure to address business risks associated with hydropower development costs and development timelines could mean that opportunities for new deployment will not be realized. As detailed in the roadmap, engagement with the public, regulators, and other stakeholders is needed to address environmental considerations effectively. Continued research and analysis on energy policy and hydropower costs, benefits, and impacts are important to provide accurate information to policymakers and for public discourse.

Finally, regularly revisiting the Hydropower Vision roadmap and updating priorities across stakeholder groups and disciplines are essential to ensuring coordinated pathways toward a robust and sustainable hydropower future.

\section{Conclusions}

One of the greatest challenges for the United States in the 21st century is ensuring the availability of low-carbon, affordable, and secure energy. Hydropower has been and can continue to be a substantial contributor toward meeting that challenge. Although the hydropower industry exhibited significant growth over the past century, the factors that led to its historical growth rates are different than the contemporary opportunities and challenges the industry is facing.

The hydropower industry has increasingly responded to the needs for technical advancement and environmental protection. Continued efforts to lower costs, increase efficiencies, and incorporate the principles of environmental sustainability through technical innovation are likely to determine the scale at which hydropower contributes to the energy mix of the future.

Increasing hydropower can simultaneously deliver an array of benefits to the nation that address issues of national concern, including air quality, GHG emissions, public health, economic development, energy diversity, grid reliability, and energy and water security. Based on the benefit and cost quantifications of the Hydropower Vision, the overall value of these types of long-term social benefits can be significant. 
Hydropower has provided clean, affordable, reliable, and renewable electricity in the United States for more than a century. Building on hydropower's historical significance, and to inform the continued technical evolution, energy market value, and environmental performance of the industry, the U.S. Department of Energy's (DOE's) Wind and Water Power Technologies Office has led a first-of-its-kind comprehensive analysis focused on a set of potential pathways for the environmentally sustainable expansion of hydropower (hydropower generation and pumped storage) in the United States.1,2

The Hydropower Vision analysis finds that U.S. hydropower could grow from 101 gigawatts (GW) of capacity to nearly $150 \mathrm{GW}$ by 2050 . Growth under this modeled scenario would result from a combination of $13 \mathrm{GW}$ of new hydropower generation capacity (upgrades to existing plants, adding power at existing dams and canals, and limited development of new stream-reaches), and $36 \mathrm{GW}$ of new pumped storage capacity. If this level of growth is achieved, benefits such as a savings of $\$ 209$ billion from avoided greenhouse gas (GHG) emissions could be realized, of which $\$ 185$ billion would be attributable to operation of the existing hydropower fleet. With this deployment level, more than 35 million average U.S. homes could be powered by hydropower in 2050 .

Transformative technical innovations able to meet the co-objectives of environmental sustainability and low-carbon energy will be critical to enabling additional hydropower growth beyond these levels.
Formulated through a broad-based collaborative effort of many stakeholders, the Hydropower Vision initiative was undertaken to realize four primary goals:

1. Document the history and existing state of hydropower in the United States, including key technical advancements, societal benefits, industry trends, and opportunities to facilitate sustainable development and operations;

2. Identify potential pathways for hydropower to maintain and expand its contributions to the electricity and water management needs of the nation from the present through 2030 and 2050, including supporting the growth of other renewable energy technologies, reducing carbon emissions, improving air quality, reducing water used for thermal cooling in the power sector, and fostering economic development and job growth;

3. Examine critical environmental and social factors to assess how existing hydropower operations and potential new projects can be operated and delivered to minimize adverse effects and contribute to responsible stewardship of waterways and watersheds to realize the highest benefit; and

4. Develop a roadmap identifying sets of stakeholder actions that could support continued responsible planning, operations, and expansion of hydropower facilities.

1. Hydropower as discussed in this report includes new or conventional technologies that use diverted or impounded water to create hydraulic head to power turbines, and PSH facilities in which stored water is released to generate electricity and then pumped back during periods of excess generation to replenish a reservoir. Throughout this report, the term "hydropower" generally encompasses all categories of hydropower. If a distinction needs to be made, the term "hydropower generation" distinguishes other types of projects from "pumped storage hydropower," or "PSH".

2. This report does not address marine (wave, current, and tidal) and river hydrokinetic technologies, as marine and hydrokinetic technologies are defined by Congress as separate and distinct from hydropower (Energy Policy Act of 2005. Public Law No: 109-58. 42 U.S.C. § 931 (a)(2) (D) Hydropower and 42 U.S.C. \& 931 (a)(2)(E)(i) Miscellaneous Projects. https://www.congress.gov/109/plaws/pub/58/PLAW-109pub/58.pdf). 
The Hydropower Vision report resulted from DOE's collaboration with more than 300 experts from over 150 hydropower industry companies, environmental organizations, state and federal governmental agencies, academic institutions, electric power system operators, research institutions, and other stakeholder groups. Collectively, these participants were instrumental in documenting the state of the industry and identifying future opportunities for growth, as well as pinpointing challenges that need to be addressed to ensure that hydropower continues to evolve and contribute value to the nation for decades to come.

Hydropower Vision: Responsibly operate, optimize, and develop hydropower in a manner that maximizes opportunities for low-cost, low-carbon renewable energy production, economic stimulation, and environmental stewardship to provide long-term benefits for the nation.

For purposes of the Hydropower Vision, sustainable hydropower projects are those that are sited, designed, constructed, and operated to meet or optimize social, environmental, and economic objectives at multiple geographic scales (i.e., national, regional, basin, site). While hydropower development has, in some cases, had adverse effects on river systems and the species that depend upon them, hydropower offers many benefits and continues to make advances in environmental performance. Accordingly, the Hydropower Vision sets increasing expectations for new hydropower development under which environmental gains are maintained and the trend of improvement continues. Sustainable hydropower fits into the water-energy system by ensuring that the ability to meet energy needs is balanced with the functions of other water management missions in the present as well as into the years ahead. In some cases, dam removal and site restoration may be part of meeting the sustainability objective.

\section{ES.1.1 Hydropower Vision Framework}

The Hydropower Vision aims to document a set of pathways to responsibly operate, optimize, and develop hydropower in a manner that maximizes opportunities for low-carbon renewable energy production, economic stimulation, and environmental stewardship to provide long-term benefits for the nation. This Vision is grounded in three foundational principles or "pillars"-optimization, growth, and sustainability-arrived at through extensive stakeholder input as being critical to ensuring the integrity of the research, modeling, and analysis conducted during the Hydropower Vision process (see Chapter 1). These are defined as follows:

- Optimization: Optimize the value and the power generation contribution of the existing hydropower fleet within the nation's energy mix to benefit national and regional economies, maintain critical national infrastructure, and improve energy security.

- Growth: Explore the feasibility of credible longterm deployment scenarios for responsible growth of hydropower capacity and energy production.

- Sustainability: Ensure that hydropower's contributions toward meeting the nation's energy needs are consistent with the objectives of environmental stewardship and water use management.

Through these foundational principles, both existing hydropower and future hydropower development were assessed, and a roadmap of potential actions was developed. Seven key insights of this Hydropower Vision collaborative effort characterize the important role that hydropower has and can continue to play in the U.S. power sector:

1. Hydropower has been a cornerstone of the U.S. electric grid, providing low-cost, low-carbon, renewable, and flexible energy services for more than a century;

2. Existing hydropower facilities have high value based on their ability to provide flexible generation and energy services, ancillary grid services, multi-purpose water management, and social and economic benefits, including avoidance of criteria air pollutants ${ }^{3}$ and GHG emissions;

3. The Clean Air Act requires EPA to set National Ambient Air Quality Standards (NAAQS) for six common air pollutants (criteria pollutants) based on the human health-based and/or environmentally-based criteria. https://www.epa.gov/criteria-air-pol/utants 
3. Hydropower has the potential to grow and contribute to additional electricity production in the future generation portfolio, including near term significant potential for economically and environmentally sustainable growth by optimizing existing infrastructure through facility upgrades and adding generation capabilities to non-powered dams (NPDs) and water conveyances, such as irrigation canals;

4. Long-term hydropower growth potential, particularly at undeveloped sites (new stream-reaches), will rely on the availability of innovative and economically competitive hydropower technologies that are not yet fully developed. The long-term potential will also depend on the extent to which new hydropower projects are able to be developed at lower costs and with improved environmental sustainability strategies;

5. The United States has significant resource potential for new pumped storage hydropower (PSH) development as a continued storage technology, enabling grid flexibility and greater integration of variable generation resources, such as wind and solar;

6. Technical design innovations, advanced project implementation strategies, optimized regulatory processes, and the application of sustainability principles will be important in determining hydropower's future; and

7. Hydropower's economic and societal benefits are significant and include substantial cost savings in avoided mortality, morbidity, and economic damages from power sector emissions of criteria air pollutants and avoided global damages from GHG emissions.

The Hydropower Vision does not specifically evaluate or recommend new policy actions but instead analyzes the feasibility and certain benefits of varied hydropower deployment scenarios, all of which could inform policy decisions at the federal, state, tribal, and local levels.

\section{ES.2 State of the U.S. Hydropower Industry}

\begin{abstract}
Hydropower (hydropower generation and pumped storage) has provided a stable and consistently low-cost energy source throughout decades of fluctuations and fundamental shifts in the electric sector, supporting development of the U.S. power grid and the nation's industrial growth in the 20th century and into the 21st century. Hydropower is a scalable, highly reliable generation technology, and it offers significant operational flexibility to maintain grid reliability and integration of variable generation resources. Hydropower infrastructure is long-lived, and the resource is generally stable and predictable over long time periods.
\end{abstract}

By the end of 2015, the U.S. hydropower generation fleet included 2,198 active power plants with a total capacity of $79.6 \mathrm{GW}$ and $42 \mathrm{PSH}$ plants totaling 21.6 GW, for a total installed hydropower capacity of 101 GW. ${ }^{4}$ The PSH capacity comprised the majority (97\%) of the utility-scale electricity storage in the
United States at the end of 2015. As of the end of 2015, hydropower was installed in 48 states. The geographic distribution of existing hydropower capacity in the United States is shown in Figure ES-1 and Figure ES-2, and cumulative deployment from 1890 to 2015 is shown in Figure ES-3. The majority of hydropower generation was installed between 1950 and 1990, and the majority of PSH was installed between 1960 and 1990 to complement operation of large, baseload coal and nuclear power plants and to cost-effectively balance electricity load and demand on the transmission grid.

\begin{abstract}
Hydropower provided $6.2 \%$ of net U.S. electricity generation and approximately half (48\%) of all U.S. renewable power in 2015. Hydropower has supplied a cumulative $10 \%$ of U.S. electricity generation over the past 65 years (1950-2015), and 85\% of cumulative U.S. renewable power generation over the same time period. ${ }^{5}$ As of 2013 , hydropower supported
\end{abstract}

4. Uria-Martinez, R., P. O’Connor, M. Johnson. April 2015. “2014 Hydropower Market Report”. Prepared by Oak Ridge National Laboratory for the U.S. Department of Energy. DOE/EE 1195. Accessed July 5, 2016. http://energy.gov/eere/water/down/oads/2014-hydropower-market-report

5. U.S. Energy Information Administration. October 27, 2015. Table 7.2b Electricity Net Generation: Electric Power Sector. Monthly Energy Review. Accessed July 5, 2016. http://www.eia.gov/totalenergy/data/monthly/ 


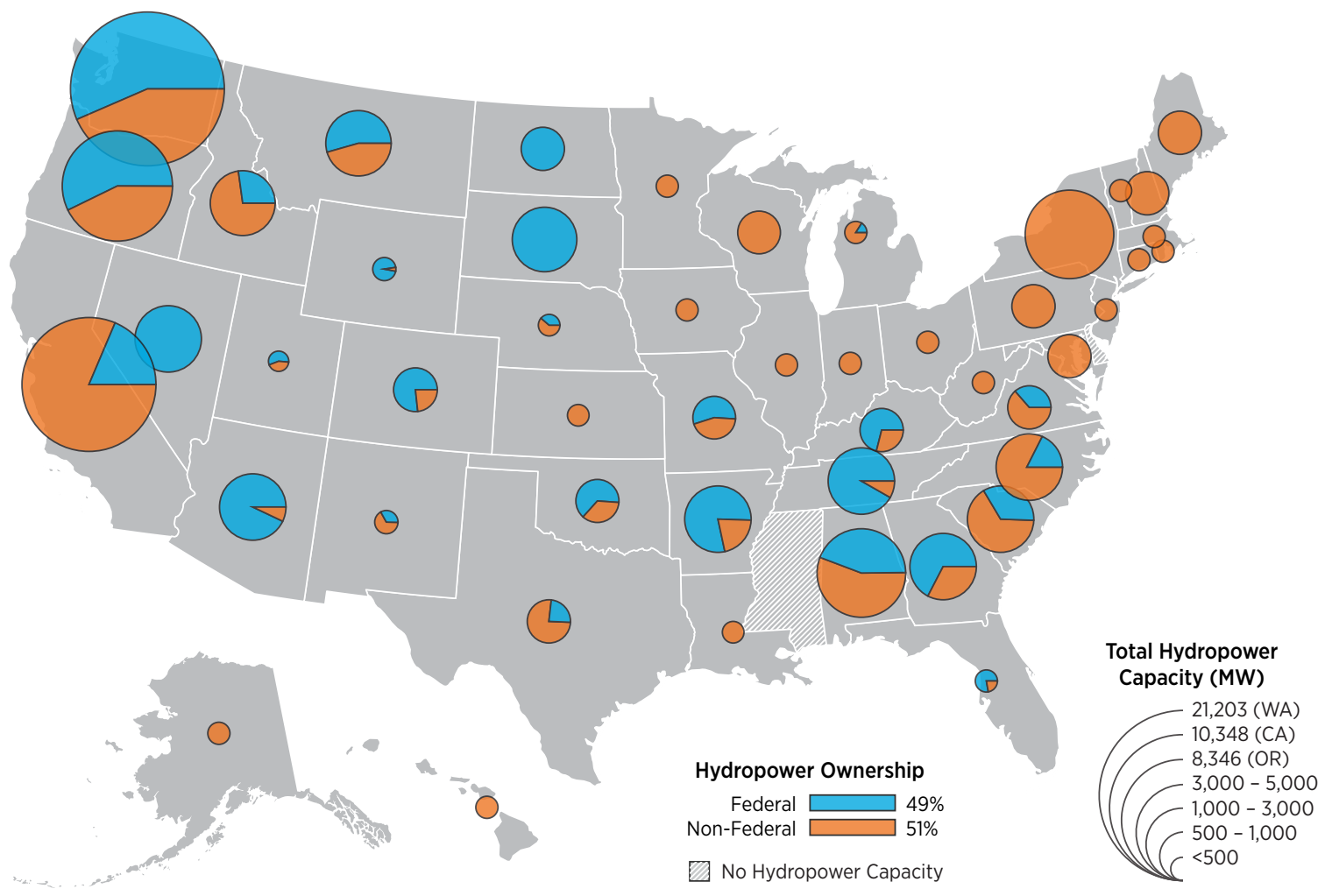

Figure ES-1. Existing hydropower generation capacity in the United States (79.6 GW)

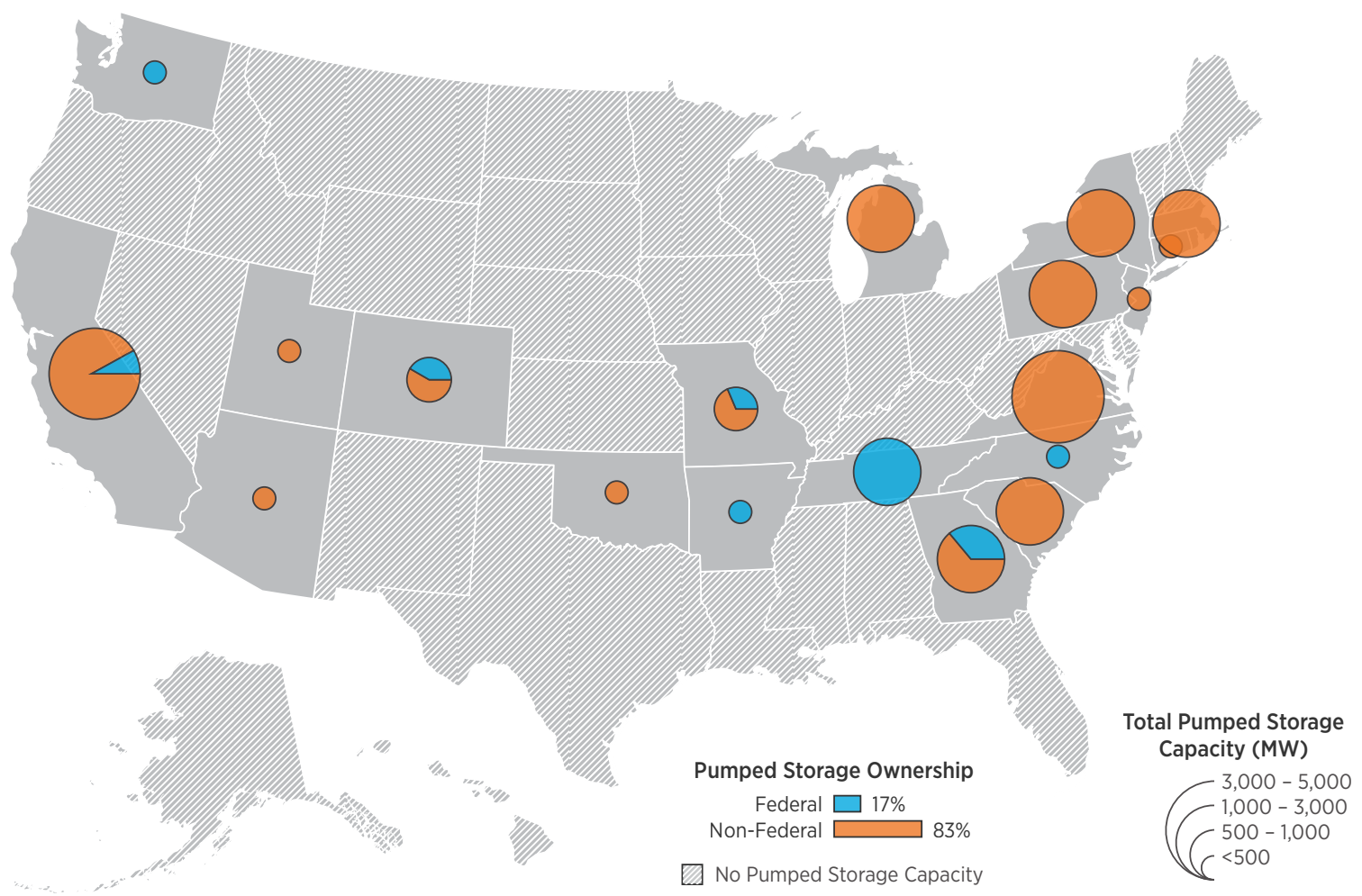

Figure ES-2. Existing pumped storage hydropower capacity in the United States (21.6 GW) 


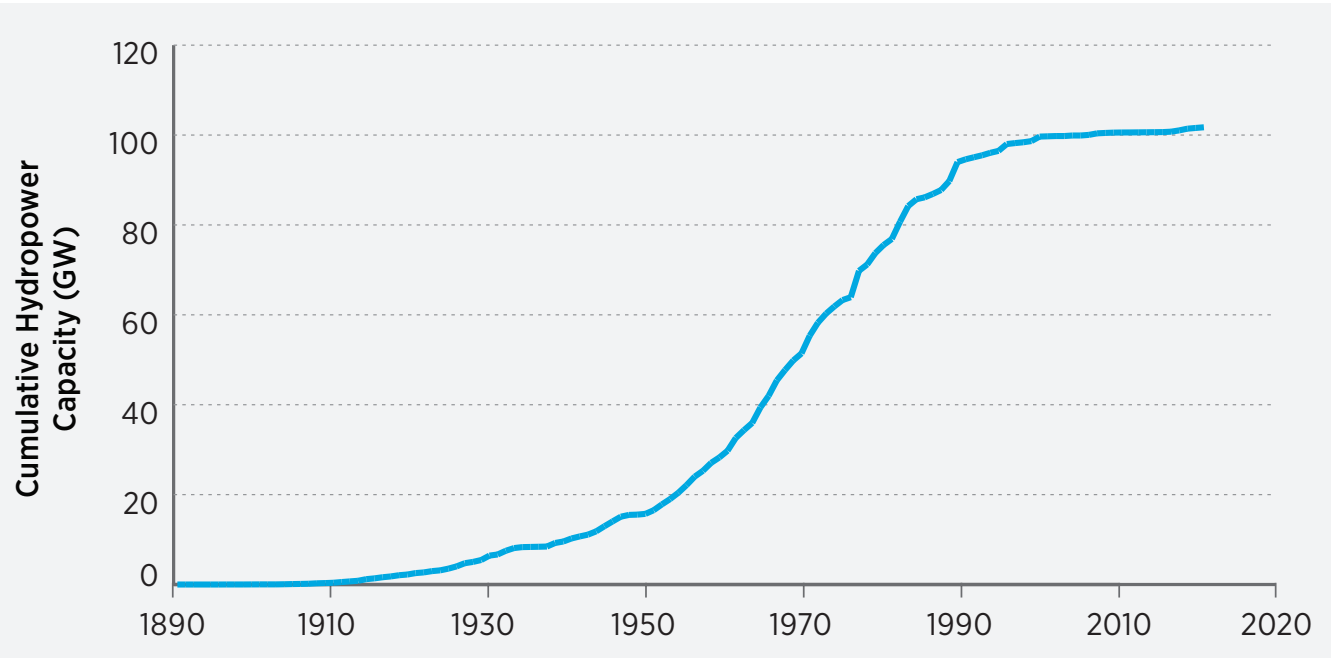

Figure ES-3. Cumulative U.S. hydropower capacity (GW), 1890-2015

approximately 143,000 jobs in the United States, including 118,000 total ongoing full-time equivalent jobs in operations and maintenance, and 25,000 temporary jobs in construction and upgrades. ${ }^{6,7}$

\section{Ownership of the existing hydropower fleet is diverse.}

Federal agency ownership (including the U.S. Army Corps of Engineers, the U.S. Bureau of Reclamation, and the Tennessee Valley Authority) accounts for the majority (approximately 49\%) of installed capacity; public ownership (including public utility districts, irrigation districts, states, and rural cooperatives) accounts for approximately $24 \%$ of installed capacity; and private ownership (including investor-owned utilities, independent power producers, and industrial companies) accounts for approximately $27 \%$ of installed capacity.

\section{Hydropower has provided a cumulative $10 \%$ of U.S. electricity generation over the past 65 years (1950-2015), and 85\% of cumulative U.S. renewable power generation over the same time period.}

\section{ES.2.1 Public, Market, and Policy Trends}

The role and emerging future of hydropower is complex given that dams and reservoirs serve many functions, including flood management and control, irrigation, recreation, navigation, and drinking water supply. The vast majority of the more than 87,000 existing dams in the United States ${ }^{8}$ do not include hydropower generation plants. Those that do generate electricity (less than 2,200, or 3\%) must meet both the ongoing power and non-power needs of multiple and varied interests and stakeholders within the context of complex regulatory frameworks.

Reliable electricity delivery is increasingly important in the global flow of information and commerce, and the cost of power interruptions-whether accidental or intentional-makes power system stability and reliability ever more critical to national security. The U.S. Department of Homeland Security lists the energy sector and the dams sector as two of the sixteen national critical infrastructures. ${ }^{9}$ These infrastructures have assets, systems, and networks so vital

6. National Renewable Energy Laboratory, Conventional Hydropower Jobs and Economic Development Impacts (JEDI) model. Last updated November 5, 2015. Accessed July 5, 2016. http://www.nrel.gov/analysis/jedi/.

7. U.S. Department of Energy. Prepared by Navigant Consulting, Inc. DOE/EE-1400. Forthcoming (2016). "United States Hydropower Workforce Assessment and Future Scenarios".

8. U.S. Army Corps of Engineers. 2013 National Inventory of Dams. May 26, 2015. Accessed July 5, 2016. http://nid.usace.army.mil.

9. "Critical Infrastructure Sectors." Last published October 27, 2015. U.S. Department of Homeland Security. Accessed July 5, 2016. https:// www.dhs.gov/critical-infrastructure-sectors. 
to the nation that their incapacitation or destruction would have a debilitating effect on physical security, economic security, and public health and safety.

Changes and trends in the electric sector call for a fresh look at the future role for hydropower. Lower natural gas prices, as well as coal and nuclear power plant retirements, contribute to a changing generation mix and potential markets for new generation sources. An increasing need to integrate variable generation resources, such as solar and wind, will lead to greater demand for grid flexibility and balancing services. Hydropower generation and PSH provide these needed services due to their consistent availability and their capability for rapid response to changes in demand.

Key market drivers of energy storage for grid and ancillary services-which PSH provides-include (1) substantial growth in variable generation; (2) governmental focus on initiatives to reduce carbon emissions; (3) the need for grid infrastructure modernization; and (4) the need to improve the resilience of the electrical grid to unforeseen interruptions. ${ }^{10}$

Public policy has long supported deployment of renewable energy at state and regional levels through policies such as renewable portfolio standards and regional GHG initiatives. Increasing concern about the effects of carbon emissions on climate change led the U.S. Environmental Protection Agency in 2015 to issue carbon pollution standards through the Clean Power Plan, which instructs states to begin making meaningful progress toward reductions by 2022." As policies develop, hydropower can play a role in carbon emissions reductions.

\section{ES.2.2 Opportunities and Challenges for Hydropower}

Hydropower's system benefits are large and have historically underpinned the nation's electric systems. Hydropower's growth is critically coupled with innovation that can enable hydropower resource opportunities to be economically competitive and environmentally sustainable in the context of other low-carbon energy options. Keys to improved competitiveness are continued technical innovation to reduce capital and operating expenses, improved understanding and market valuation of system-wide grid reliability and stability services, and recognition and valuation of societal benefits from avoided power sector air pollution and GHG emissions.

Equally important to increasing hydropower's competitiveness are continued improvement in mitigating adverse effects, protection of fish and wildlife, and increased public awareness of progress made in this regard. Addressing these objectives will require continued technical innovation, measurable and implementable environmental sustainability metrics and practices, increased planning at the basin or watershed scale, and access to new science and assessment tools.

Inherent market and regulatory challenges must be overcome to realize hydropower's potential to improve grid flexibility and facilitate integration of variable generation resources. The full valuation, optimization, and compensation for hydropower generation and ancillary services in power markets is difficult, and not all benefits and services provided by hydropower facilities are readily quantifiable or financially compensated in today's market framework. In traditional and restructured markets, as well as in emerging environmental markets, many hydropower services and contributions are not explicitly monetized. In some cases, market rules undervalue operational flexibility, which is important to maintaining grid reliability and is a prime attribute of hydropower.

\section{In April 2016, the Federal Energy Regulatory Commission initiated Docket No. AD16-20-000 to examine whether barriers exist to the participation of electric storage resources-including PSH-in the capacity, energy, and ancillary service markets, potentially leading to unjust and unreasonable wholesale rates. According to the Commission, this was motivated in part by trends of increasing explo- ration of the value electric storage resources may provide to the grid when acting as both generation and load and providing transmission services. ${ }^{12}$}

10. Eller, A. and A. Dehamna. Energy Storage for the Grid and Ancillary Services. Navigant Consulting, Inc. May 2016 (paid report). Accessed July 5, 2016. https://www.navigantresearch.com/research/energy-storage-for-the-grid-and-ancillary-services.

11. U.S. Environmental Protection Agency. Clean Power Plan for Existing Power Plants. Accessed May 8, 2016. https://www.epa.gov/ cleanpowerplan/clean-power-plan-existing-power-plants.

12. Federal Energy Regulatory Commission. Open Commission Meeting. Staff Presentation Item A-4. April 21, 2016. Accessed July 5, 2016. http://www.ferc.gov/CalendarFiles/20160421110616-A-4-Presentation.pdf. 
Uncertainty in licensing-related processes and outcomes may adversely affect development costs, timelines and financing options. Existing laws and regulations governing hydropower ensure that project development and operations are carried out responsibly and consistently. However, stakeholders have expressed concerns that regulatory process inefficiencies, overlaps, and interpretations can lead to delays and costs that result in long-term business risks to hydropower owners, operators, and developers.

Future development of hydropower projects at previously undeveloped sites and waterways is likely to remain limited without innovative-even transformational-advances in technologies and project development methods to meet sustainability objectives. Ongoing research and development activities, including non-traditional approaches, can lead to significant changes in the cost, configuration, and function of hydropower facilities that could transform development of new hydropower projects in the decades to come.
Climate change creates uncertainty around water availability for hydropower generation, and this uncertainty can affect the long-term outlook of the hydropower industry. Water availability - including more water in some areas and less in others-affects the energy production potential of hydropower resources, which in turn influences their economic attractiveness in the electric sector. A changing climate may also potentially impact water quality (e.g., temperature) and availability of water for thermal power plant cooling, while changing temperatures may impact electricity demand.

The degree to which these challenges can be effectively addressed will influence the levels of future hydropower growth and reinvestment in existing facilities and realization of the opportunities and benefits that the low costs, grid services, and long project operating life of hydropower can provide. See Chapter 2 for detailed discussion of the state of the industry and its trends, opportunities, and challenges.

\section{ES.3 Modeling Hydropower's Contributions and Future Potential}

For the Hydropower Vision report, computational electric sector models provided the foundation to carry out comprehensive analyses of the existing and future role of hydropower (hydropower generation and pumped storage) within the electric sector on a national scale. These analytical modeling methods were used to evaluate a range of possible future outcomes for hydropower deployment based on potential technical innovation, economic factors, national priorities, stakeholder action or inaction, market forces, and requirements of environmental mitigation and environmentally sensitive areas. Because growth potential is tied to a set of complex and unpredictable variables, modeling results serve primarily as a basis to identify key factors and drivers that are likely to influence future pathways. Modeling results in the Hydropower Vision should not be interpreted as DOE predictions or targets.
The primary tool used to assess potential growth trajectories and the basis to evaluate resulting cost and benefit impacts is the National Renewable Energy Laboratory's (NREL's) Regional Energy Deployment System (ReEDS) model..$^{13}$ ReEDS is an electric sector capacity expansion model that simulates the cost of construction and operation of generation and transmission capacity to meet electricity demand and other power system requirements on a competitive basis over discrete study periods -2017 , through 2030, and through 2050. Results from ReEDS include estimated electricity generation, geographic distribution of new electricity infrastructure additions, transmission requirements, and capacity additions of power generation technologies built and operated during the study period.

13. Short, W.; Sullivan, P.; Mai, T.; Mowers, M.; Uriarte, C.; Blair, N.; Heimiller, D.; Martinez, A. Regional Energy Deployment System (ReEDS). NREL/TP-6A20-46534. Golden, CO: National Renewable Energy Laboratory, December 2011; 94 pp. Accessed June 30, 2016: http://www. nrel.gov/analysis/reeds/documentation.html. 
The modeling analysis assumes policy as legislated and effective on December 31, 2015, including the U.S. Environmental Protection Agency's Carbon Pollution Standards for Existing Power Plants (Clean Power Plan). This analysis cannot comprehensively represent all of the costs or benefits of hydropower. The analysis includes four metrics that DOE can objectively and transparently estimate using best available data, including GHG emissions avoidance. This analysis also does not attempt to assess the costs for past, present, or future environmental impacts and solutions, such as resource protections needed to mitigate potential effects on fish and wildlife.

Both the existing hydropower fleet and the potential for new development are included in the quantitative modeling. Although deployment of existing hydropower facilities occurred over more than a century, modeling results indicate that important growth opportunities remain. Hydropower resource opportunities for potential growth fall into four distinct categories:

1. Existing power plants and dams that can be upgraded and optimized for increased production and environmental performance;

2. New power plants at existing non-powered dams and water conveyances such as canals and conduits that are not powered but could be cost-effectively leveraged to support hydroelectric facilities;

3. New and existing pumped storage hydropower facilities and upgrades, including reservoirs and pumping/generating plants; and

4. New stream-reach development, including diversionary methods, new multi-purpose impoundments, or instream approaches.

Capacity additions from canals and conduits, resource potential in Alaska and Hawaii, and the potential for upgrades to existing PSH facilities are not currently within the ReEDS quantitative modeling framework, and therefore are not part of the modeled results. Instead, these resources are discussed qualitatively throughout the Hydropower Vision report.

\section{ES.3.1 Understanding Resource Estimates and Modeling Scenarios}

Hydropower Vision uses the best available resource assessments to explore hydropower's market potential. The process of converting existing estimates of total physical or technical resource potential ${ }^{14}$ to a modeling result of realistically potential deployment requires making technical, economic, physical, and geographic assumptions and corrections. These assumptions and corrections reduce the size of the resource base to that which will be available to the model.

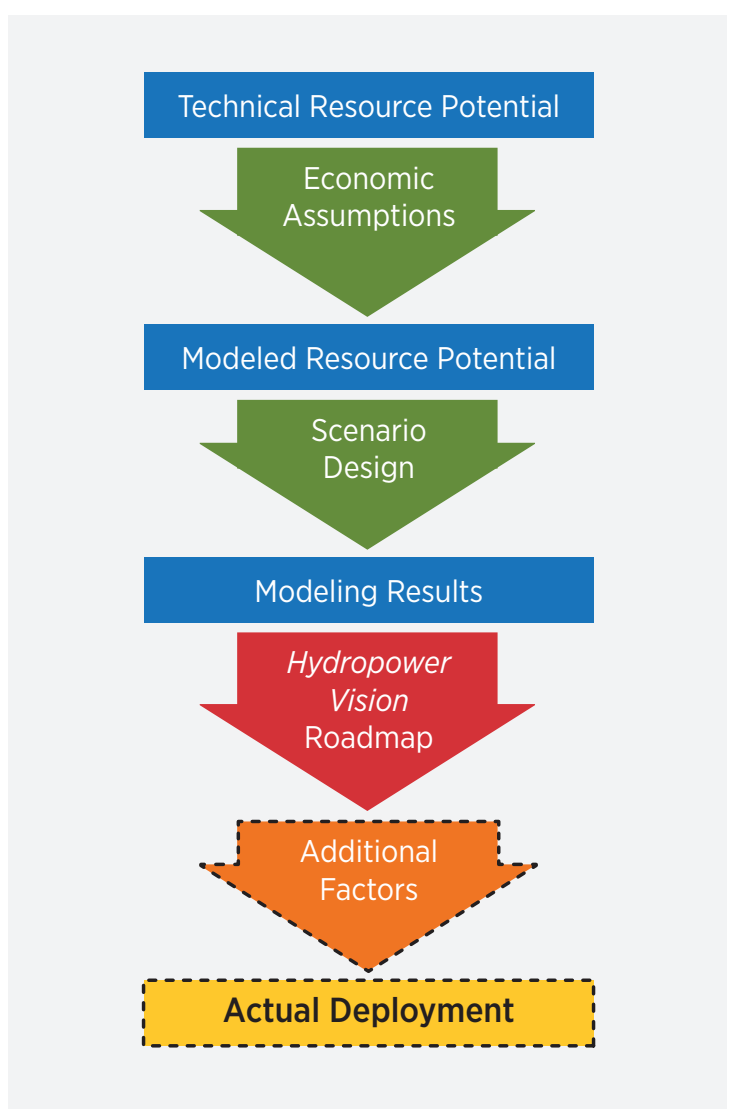

Figure ES-4. Process flow for interpreting hydropower's future market potential from technical resource assessments

14. The technical potential of a specific renewable electricity generation technology estimates energy generation potential based on renewable resource availability and quality, technical system performance, topographic limitations, environmental, and land-use constraints only. The estimates do not consider (in most cases) economic or market constraints, and therefore do not represent a level of renewable generation that might actually be deployed. Source: A. Lopez, Roberts, B., Heimiller, D., Blair, N., and Porro, G. U.S. Renewable Energy Technical Potentials: A GIS-Based Analysis. National Renewable Energy Laboratory. July 2012. NREL/TP-6A20-51946. Accessed June 27, 2016. http:// www.nrel.gov/docs/fy12osti/51946.pdf. 
The process flow for interpreting hydropower's future market potential from technical resource assessments is represented by Figure ES-4. The initial resource base considered is denoted in the figure by the "Technical Resource Potential." This resource potential is then reduced to the resource potential available to a capacity expansion model by applying economic and other assumptions and corrections, resulting in the "Modeled Resource Potential." The potential for market deployment is calculated for future scenarios, denoted in the figure by "Modeling Results."

Parameters and assumptions for modeling future deployment scenarios include cost reduction through technology advancement, cost reduction though innovative financial mechanisms, consideration of social and environmental objectives, changes in fossil fuel costs over time, future market penetration of variable generation sources, potential effects of climate change, and others. See Chapter 3 for detailed discussion of resource assessments, the modeling methodology, and modeling results.

While modeling results identify potential deployment pathways and the influence of key parameters, they do not-and cannot-indicate what actual future deployment may be. As indicated by Figure ES-4, actual deployment will be influenced by additional factors, including macroeconomic conditions, social and environmental considerations, policy, and others that are beyond the scope of the Hydropower Vision analysis. The Hydropower Vision roadmap (Chapter 4) provides a broad set of actions stakeholders may take to pursue opportunities for potential deployment identified in the modeling results.

\section{ES.3.2 Understanding the Future Potential for Hydropower}

More than $\mathbf{5 0}$ total hydropower deployment scenarios were evaluated by varying hydropower-specific parameters as well as broader non-hydropower specific parameters. The Hydropower Vision analysis found that the key drivers influencing deployment of new hydropower capacity were: (1) technology innovation to reduce cost; (2) improved market lending conditions that value the long asset life of hydropower facilities; and (3) the concurrent influence of environmental considerations.

To consider the future potential for hydropower, the Hydropower Vision assesses the impacts of the key drivers through an Advanced Technology scenario, assuming significant hydropower cost reductions through innovation; a Low Cost Finance scenario, assuming cost savings based on lending terms with longer asset life; and a scenario combining Advanced Technology and Low Cost Finance scenario settings with a set of Combined Environmental Considerations to explore the concurrent influence of environmental considerations and services. ${ }^{15}$ Additional scenarios included for reference purposes are a Business-asUsual scenario that assumes continuation of existing, projected, and evolving trends, and a baseline scenario of no new unannounced hydropower to provide a reference baseline and enable social and economic impacts to be calculated. Table ES-1 summarizes assumptions that are constant across all scenarios, including Business-as-Usual. Table ES-2 summarizes the resource estimates and modeled resource potential used in the analysis, and model results for selected scenarios.

\section{The combined effect of the Advanced Technology and Low Cost Finance assumptions in lowering cost is greater than each effect individually. For new hydro- power generation capacity, Advanced Technology assumptions alone have little effect-an additional 0.8 GW by 2050 as compared to $5.2 \mathrm{GW}$ under Business- as-Usual; while Low Cost Finance assumptions alone provide only a modest increase-an additional $1.8 \mathrm{GW}$}

15. The Combined Environmental Considerations scenario avoids NSD resource overlapping with seven environmental considerations and services (critical habitats, ocean connectivity, migratory fish habitat, species of concern, protected lands, national rivers inventory, and low disturbance rivers) to illustrate that accommodating the wide variety of existing values of uses of stream-reaches with NSD potential is essential for realizing sustainable hydropower potential. Regulatory permitting processes are parameters that cannot be varied in the model. 
Table ES-1. Constants across Modeled Scenarios

\begin{tabular}{|l|l|}
\hline \multicolumn{1}{|c|}{ Input Type } & \multicolumn{1}{c|}{ Input Description } \\
\hline Electricity demand & $\begin{array}{l}\text { AEO 2015 Reference Case (average annual electricity demand } \\
\text { growth rate of 0.7\%) }\end{array}$ \\
\hline Fossil technology and nuclear power & AEO 2015 Reference Case \\
\hline $\begin{array}{l}\text { Non-hydro/wind/solar photovoltaics } \\
\text { renewable power costs }\end{array}$ & NREL Annual Technology Baseline 2015 Mid-Case Projections \\
\hline Policy & As legislated and effective on December 31, 2015. ${ }^{\text {a }}$ \\
\hline Transmission expansion & $\begin{array}{l}\text { Pre-2020 expansion limited to planned lines; post-2020, economic } \\
\text { expansion, based on transmission line costs from Eastern } \\
\text { Interconnection Planning Collaborative }\end{array}$ \\
\hline
\end{tabular}

Note: "AEO" refers to the U.S. Electricity Information Administration's Annual Energy Outlook.

a. Though the Supreme Court issued a stay of the Clean Power Plan (CPP) in February 2016, the CPP is treated as law in all scenarios. The CPP is modeled using mass-based goals for all states with national trading of allowances available. Although states can ultimately choose rate- or mass-based compliance and will not necessarily trade with all other states, a nationally traded mass-based compliance mechanism is viewed as a reasonable reference case for the purpose of exploring hydropower deployment under a range of electricity system scenarios.

by 2050 as compared to Business-as-Usual deployment. However, by combining the two and taking into account sustainability principles through the Combined Environmental Considerations assumptions, an additional $7.6 \mathrm{GW}$ is deployed as compared to Business-as-Usual, for a total of $12.8 \mathrm{GW}$ of new generation capacity by 2050 (Figure ES-5 and Table ES-2). Nearly three-quarters (73\%) of this capacity (9.4 GW) is deployed by 2030 (Table ES-3).

The majority of the $12.8 \mathrm{GW}$ of new capacity through 2050 is from upgrades to existing facilities $-5.2 \mathrm{GW}$ is added under Business-as-Usual, and an additional $1.1 \mathrm{GW}$ is added under the Advanced Technology, Low Cost Finance, Combined Environmental Considerations scenario for a total of $5.8 \mathrm{GW}$ from upgrades to existing facilities (Figure ES-6). To this, $40 \mathrm{MW}$ is added from the powering of NPDs under Business-as-Usual; and $4.8 \mathrm{GW}$ is added from the powering of NPDs and 1.7 GW from NSD, both under the Advanced Technology, Low Cost Finance, Combined Environmental Considerations scenario.

For new PSH capacity, Advanced Technology assumptions alone have a modest effect (2.6 GW by 2050) as compared to Business-as-Usual deployment (0.5 GW in 2050), while Low Cost Finance assumptions alone provide a significant increase in deployment,

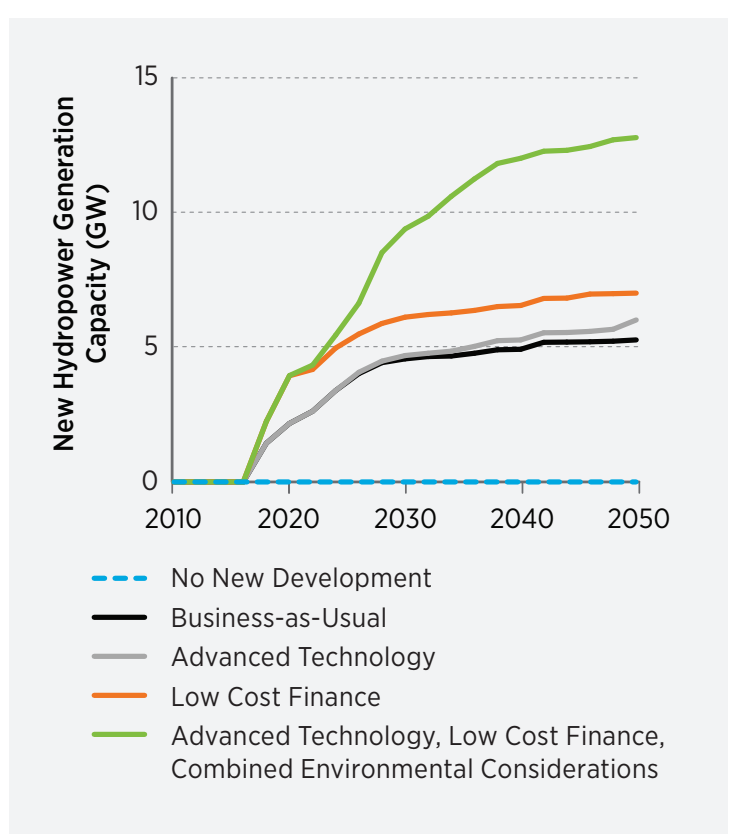

Figure ES-5. ReEDS modeled deployment of new hydropower generation capacity, selected scenarios, 2017-2050 (GW) 


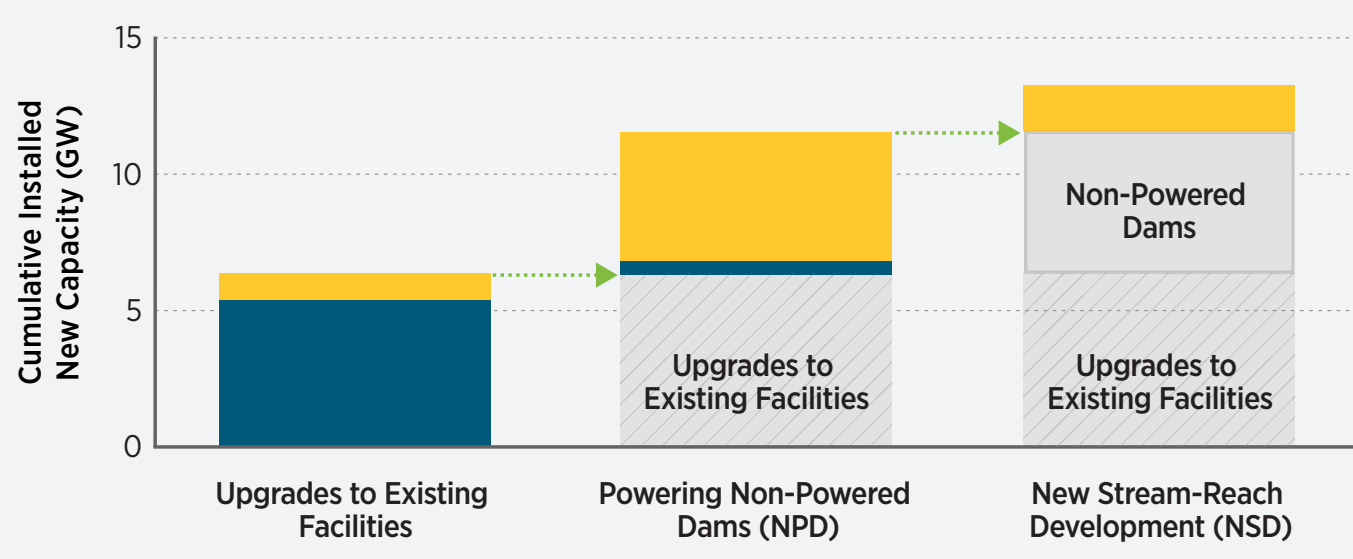

Advanced Technology, Low Cost Finance, Combined Environmental Considerations

Business-as-Usual

Figure ES-6. ReEDS modeled cumulative 2050 deployment of new hydropower generation capacity by resource category (GW)

with 22.6 GW by 2050 (see Figure ES-7). Under the scenario combining Advanced Technology, Low Cost Finance, Combined Environmental Considerations, 35.5 GW of new PSH capacity deployment occurs by 2050 (see Table ES-1), with approximately half of this (16.2 GW, or 53\%) occurring by 2030 (see Table ES-2).

Deployment of new advanced PSH technology with improved capabilities, such as closed-loop adjustable-speed, can facilitate integration of variable generation-including wind and solar-due to its ability to provide needed operating reserves, grid flexibility, and system inertia. With increased PSH deployment under Advanced Technology and Low Cost Finance assumptions, PSH provides more operating reserves (52\%) than any other technology by 2050. As discussed in Text Box ES-1, the Hydropower Vision analysis indicates there is a positive correlation between PSH and variable generation resource deployment.

Notable observations from the analysis of deployment beyond Business-as-Usual include:

- U.S. hydropower could grow from $101 \mathrm{GW}$ of combined generating and storage capacity in 2015 to nearly $150 \mathrm{GW}$ by 2050;

- In the near term (before 2030), hydropower generation growth is likely to be driven primarily by optimizing and upgrading the existing fleet, and powering non-powered dams;

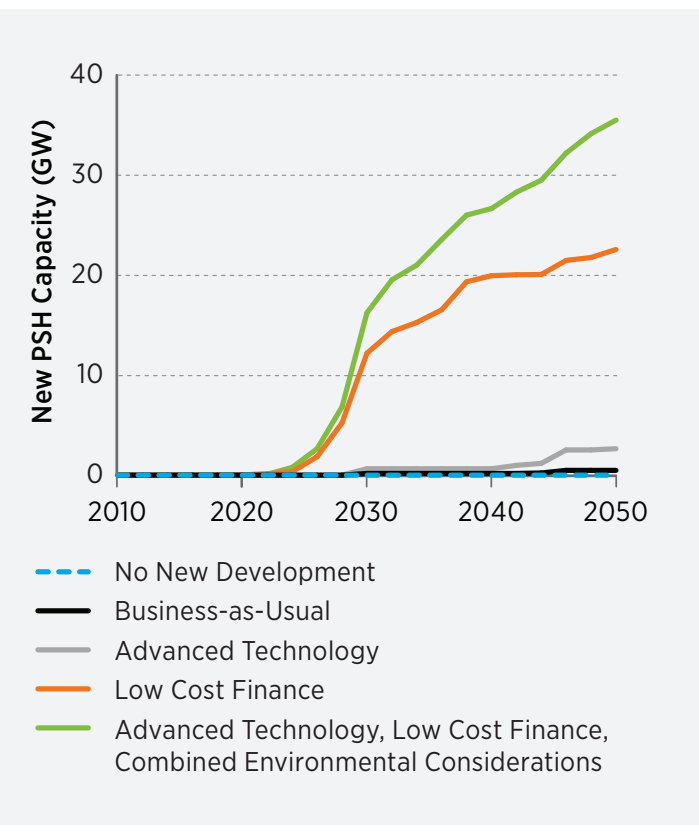

Figure ES-7. ReEDS modeled deployment of new pumped storage hydropower capacity, selected scenarios, 2017-2050 (GW) 
Table ES-2. Resource Estimates, Modeled Resource Potential, and Modeling Results for Cumulative Hydropower Capacity Additions in the United States under Selected Scenarios, 2050

\begin{tabular}{|c|c|c|c|c|c|c|}
\hline \multirow[b]{2}{*}{ Resource Category } & \multirow[b]{2}{*}{$\begin{array}{c}\text { Technical } \\
\text { Resource } \\
\text { Potential } \\
(\mathbf{G W})^{\mathrm{a}}\end{array}$} & \multirow[b]{2}{*}{$\begin{array}{l}\text { Modeled } \\
\text { Resource } \\
\text { Potential } \\
(\mathrm{GW})^{\mathrm{b}}\end{array}$} & \multicolumn{4}{|c|}{ Modeling Results by Scenario, 2050} \\
\hline & & & $\begin{array}{l}\text { Business- } \\
\text { as-Usual } \\
\text { Reference } \\
\text { (GW) }\end{array}$ & $\begin{array}{l}\text { Advanced } \\
\text { Technology } \\
\text { Only (GW) }\end{array}$ & $\begin{array}{l}\text { Low Cost } \\
\text { Finance } \\
\text { Only (GW) }\end{array}$ & $\begin{array}{c}\text { Advanced } \\
\text { Technology, Low } \\
\text { Cost Finance, } \\
\text { Combined } \\
\text { Environmental } \\
\text { Considerations } \\
\text { (GW) }\end{array}$ \\
\hline $\begin{array}{l}\text { Upgrades and } \\
\text { Optimization of Existing } \\
\text { Hydropower Plants }\end{array}$ & $\begin{array}{l}8-10 \% \\
\text { increase in } \\
\text { generation }\end{array}$ & 6.9 & 5.2 & 5.2 & 6.3 & 6.3 \\
\hline $\begin{array}{l}\text { Powering of Non- } \\
\text { Powered Dams }\end{array}$ & 12 & 5 & 0 & 0.8 & 0.7 & 4.8 \\
\hline $\begin{array}{l}\text { Powering Existing } \\
\text { Canals and Conduits }\end{array}$ & $\sim 2$ & \multicolumn{5}{|c|}{$\mathrm{n} / \mathrm{a}$} \\
\hline $\begin{array}{l}\text { New Stream-Reach } \\
\text { Development }^{d}\end{array}$ & 65.5 & 30.7 & 0 & 0 & 0 & 1.7 \\
\hline $\begin{array}{l}\text { New Pumped Storage } \\
\text { Hydropower }\end{array}$ & $>1,000$ & 109 & 0.5 & 2.6 & 22.6 & 35.5 \\
\hline
\end{tabular}

Note: Potential in Alaska and Hawaii is not included due to lack of contemporary high-resolution resource assessments.

a. Existing technical potential estimates for NPD were modified to include the removal of some existing dams slated for removal, and the addition of some projects omitted from the 2012 resource assessment.

b. The modeled resource potential is the portion of the technical resource potential made available to the model, e.g., economic assumptions and corrections have been applied to reduce the technical resource potential to the modeled resource potential.

c. Canals and conduits are discussed qualitatively in the report as there have been no nationwide resource assessments for them.

d. Existing technical potential estimates for NSD were modified for reaches in a handful of Western basins that were discovered to have relied on an earlier version of the site sizing methodology.

Table ES-3. Summary of Modeling Results for the Business-as-Usual and Advanced Technology, Low Cost Finance, Combined Environmental Considerations Scenarios in 2030 and 2050

\begin{tabular}{|l|c|c|c|c|}
\hline \multicolumn{1}{|c|}{ Resource Category } & \multicolumn{3}{|c|}{$\begin{array}{c}\text { Advanced Technology, Low Cost } \\
\text { Binance, Combined Environmental } \\
\text { Considerations Scenario (GW) }\end{array}$} \\
\cline { 2 - 5 } & 2030 & 2050 & 2030 & 2050 \\
\hline $\begin{array}{l}\text { Total New Hydropower } \\
\text { Generation Capacity }\end{array}$ & 4.5 & 5.2 & 9.4 & 12.8 \\
\hline $\begin{array}{l}\text { Upgrades and Optimization of } \\
\text { Existing Hydropower Plants }\end{array}$ & 4.5 & 5.2 & 5.6 & 6.3 \\
\hline Powering of Non-Powered Dams & 0.04 & 0.04 & 3.6 & 4.8 \\
\hline New Stream-Reach Development & 0 & 0 & 0.2 & 1.7 \\
\hline $\begin{array}{l}\text { New Pumped Storage } \\
\text { Hydropower Capacity }\end{array}$ & 0.2 & 0.5 & 16.2 & 35.5 \\
\hline Total New Hydropower Capacity & 4.7 & 5.7 & 25.6 & 48.3 \\
\hline
\end{tabular}


- In the mid-to-long term (2030-2050), additional growth may come through sustainable deployment of NPD and NSD; and

- PSH growth can increase substantially in both the 2030 and 2050 periods, assisting variable generation growth by providing flexibility and other important grid services (Text Box ES-1).
The analysis provides a quantitative basis for describing the characteristics of potential hydropower deployment in terms of general geographic location, type of resource deployed, resulting electric sector composition, and system cost.

\section{Text Box ES-1.}

\section{Pumped Storage Hydropower Complements Variable Generation}

The United States has significant resource potential for new PSH development. New advanced PSH technology with improved capabilities such as adjustable speed, closedloop, and modular designs can further facilitate integration of variable generation, such as wind and solar, due to its ability to provide grid flexibility, reserve capacity, and system inertia. ${ }^{\text {a }}$ The Hydropower Vision analysis (Chapter 3) indicates there is a correlation between PSH and variable generation deployment in the 2050 timeframe (Figure ES-8). The figure indicates that, under the modeling scenario combining Advanced Technology and Low Cost Finance assumptions, deployment of $35.5 \mathrm{GW}$ of new PSH by 2050 corresponds with roughly $45 \%$ of national demand met by variable generation. However, the exact relationship between PSH and variable generation resources is highly dependent on the characteristics of the generation and transmission assets within balancing areas, and the data shown here do not necessarily imply a causal relationship. Modeling does not evaluate or designate specific PSH locations within a balancing area. PSH development will require location-specific compliance with applicable regulations, including environmental considerations.

PSH is complementary to variable generation, as it can reduce curtailment of excess generation by providing load and energy storage, thus enabling greater integration of variable generation resources into the system. PSH is a proven low-risk technology with a track record of high efficiency in providing load, energy storage, and grid services. Additionally, PSH is more flexible, has longer facility lifetimes, and has lower operating costs than other technologies that can provide these services in facilitating the integration of variable generation resources onto the grid.

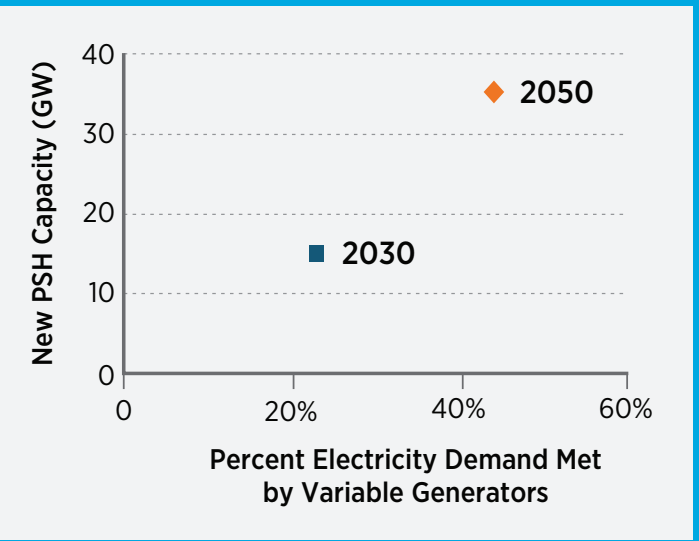

Figure ES-8. Relationship between new pumped storage hydropower growth and generation from variable generators under Advanced Technology and Low Cost Finance assumptions

Because decision makers need better information on the role and value of grid storage, key recommendations for PSH in the Hydropower Vision roadmap include the development of tools that would help evaluate the feasibility of conversion from fixed-speed to adjustable-speed technologies, and investigation of market mechanisms that would accurately compensate PSH for the full range of services provided to the power grid.

a. U.S. Department of Energy. February 2015. "Pumped Storage and Potential Hydropower from Conduits. Report to Congress." Accessed July 6, 2016. http://energy.gov/sites/prod/files/2015/06/f22/pumped-storage-potential-hydropower-from-conduits-final.pdf 
ES.3.3 Exploring New Hydropower Potential while Addressing Environmental

\section{Considerations}

The largest remaining potential for additional hydropower generation capacity is through consideration of further development of new projects on undeveloped stream-reaches. Significant federal and private investment in research and development into new and transformative hydropower technologies and project designs capable of minimizing adverse environmental and social impacts will be necessary for this resource to be considered (Text Box ES-2).

\section{ES.3.4 Technical Innovation Can Enable NSD Projects}

The results of the forward-looking analysis presented in Hydropower Vision imply that future development of projects at previously undeveloped sites and waterways (NSD) is likely to remain limited without innovative-even transformational- advances in technologies and project development methods to meet sustainability objectives. While it is difficult to predict how these advances will take shape in the coming decades, trends in innovation do offer indications of how non-traditional approaches could transform development of hydropower projects. Several examples of nascent design methodologies and technical advances and are provided in Text Box ES-3.

Text Box ES-2.

\section{Expanding the Development of New Stream-Reach Development Hydropower: A National Sustainability Challenge}

Realizing sustainable and responsible hydropower development means that protecting the wide variety of existing values of streamreaches with NSD potential is essential. To examine the influence of environmental and ecological attributes on NSD development and provide better context for the future of the hydropower industry, Hydropower Vision modeling analysis employs a series of sensitivity scenarios exploring how potential NSD deployment intersects with other existing priority uses of the nation's water resources, such as protecting habitat for key aquatic and terrestrial species, and adding drinking water supplies. Under the modeled Hydropower Vision scenarios and reflecting on the Combined Environmental Consideration scenario, the study finds that $1.7 \mathrm{GW}$ of NSD are realizable in locations where there is no overlap with areas designated to have particular environmental sensitivities by 2050 .

While as of the end of 2015, NSD is the most costly and environmentally challenging class of hydropower to develop, the hydropower community can pursue this resource by developing technology solutions that balance efficiency, economics, and environmental sustainability. This NSD resource potential provides an opportunity for the nation to look beyond the modeled $1.7 \mathrm{GW}$ deployment scenario. Such potential could be harnessed in a variety of ways, including diversionary methods, new multi-purpose impoundments, or instream approaches. Independent of the methodology considered, new technology options are needed to responsibly and effectively harness opportunities for NSD.

DOE recognizes that any given growth trajectory for NSD is subject to economic and environmental considerations. Assessments of NSD potential at the national scale account for factors that preclude development, such as designation as a National Park, Wild and Scenic River, or Wilderness Area, but even sites that appear promising when evaluated at the national scale require comprehensive feasibility assessments at watershed or basin scales. Detailed site assessments consider, for example, the potential presence of threatened and endangered species, cultural sites, and other sensitive or protected resources. Furthermore, consideration of NSD potential could be complemented by consideration of removing non-hydro, obsolete dams and barriers, where the net result could be increased energy yield and more rivers restored to natural conditions. 
Text Box ES-3.

\section{Future Hydropower Technologies}

\section{Advances in Project Evaluation and Design}

Environmentally sustainable hydropower projects should be sited, built, and operated to balance among ecological considerationssuch as species diversity, water quality, recreation, and physical processes within the ecosystem. Innovative approaches that achieve multiple objectives require integrated planning that accounts for multiple factors, including watershed, infrastructure, and socioeconomics. Figure ES-9 illustrates an integrated approach under which natural stream functionality can be taken into account in establishing design objectives, design constraints, and functional requirements during project planning and design. If environmental objectives are integrated fully into the design paradigm for components and facilities from the outset, there will be opportunities for advanced modeling, manufacturing, installation, operation, and maintenance innovations to reduce costs and improve generation and environmental performance simultaneously.

Decision making in project evaluation and design can be enhanced through identification of environmental metrics to model, evaluate, and refine the performance of hydropower systems for specific sites and watersheds. A DOE initiative, Environmental Metrics for New Hydropower, is identifying a suite of

scientifically rigorous environmental metrics for use by designers, decision makers, policy makers, researchers and other stakeholders in evaluating hydropower projects. DOE has also initiated a Basin-Scale Opportunity Assessment to develop multidisciplinary approaches and tools for basin-scale water

resource planning processes, applying Geographic Information Systems to assimilate and evaluate data in a multi-scale, hydrologic context.

Figure ES-9.

Primary linkage relations and indices for an integrated approach to hydropower development

nomics

Power generation

- Recreation

- Aesthetics - Commercial river usage

- Flood control

- Water supply
Generation

Foundation $\begin{array}{ll}\cdot \text { - Hydrology } & \cdot \text { O\&M } \\ \text { - Topography } & \end{array}$
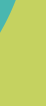

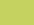

\section{- Water supply}




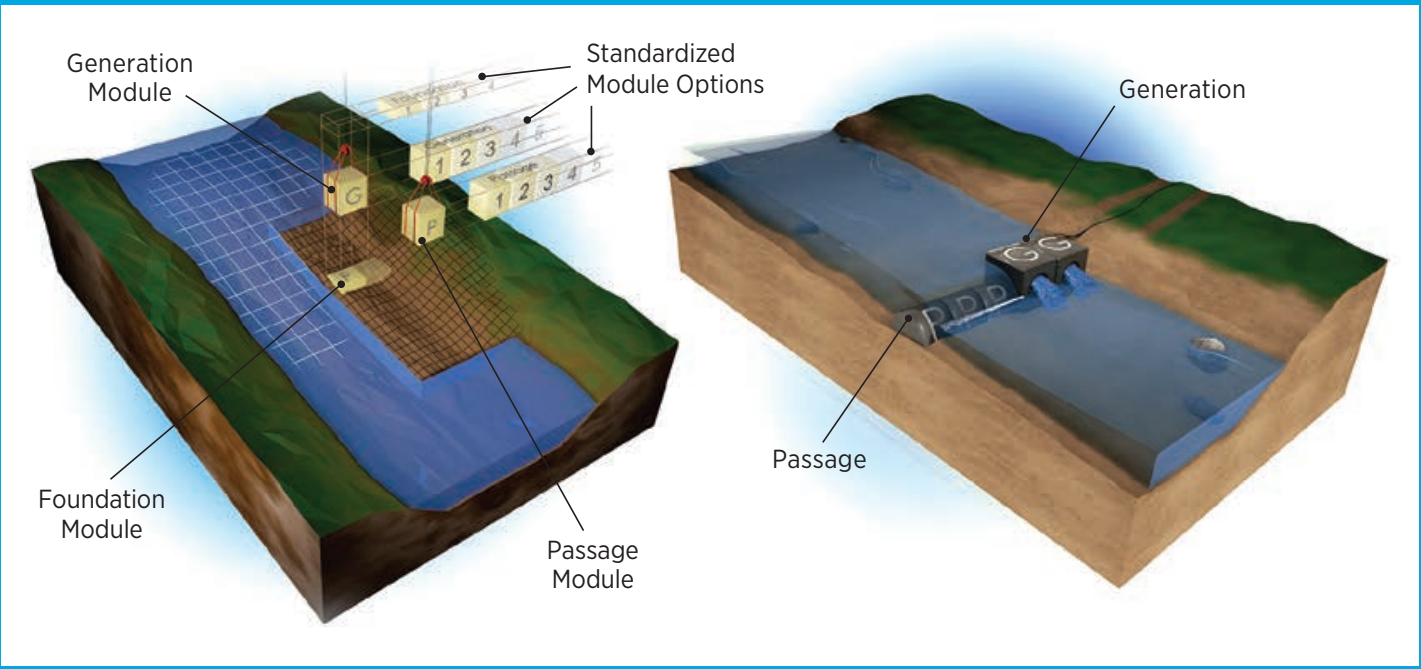

Figure ES-10. Conceptual illustration of modular approach to new in-stream hydropower facility

Potential sites for NSD are predominantly low head with variable flow rates. For these sites, estimated costs would be too high if traditional generating equipment and civil configurations were employed. Several new turbine/generator configurations illustrate how compact integrated designs can simplify facility design, limit the need for civil works, and lower lifetime maintenance requirements. Figure ES-11 offers two designs in which turbines are integrated in one housing with a permanent magnet generator, simplifying both the mechanical and electrical elements of the systems while improving overall efficiency and reliability.

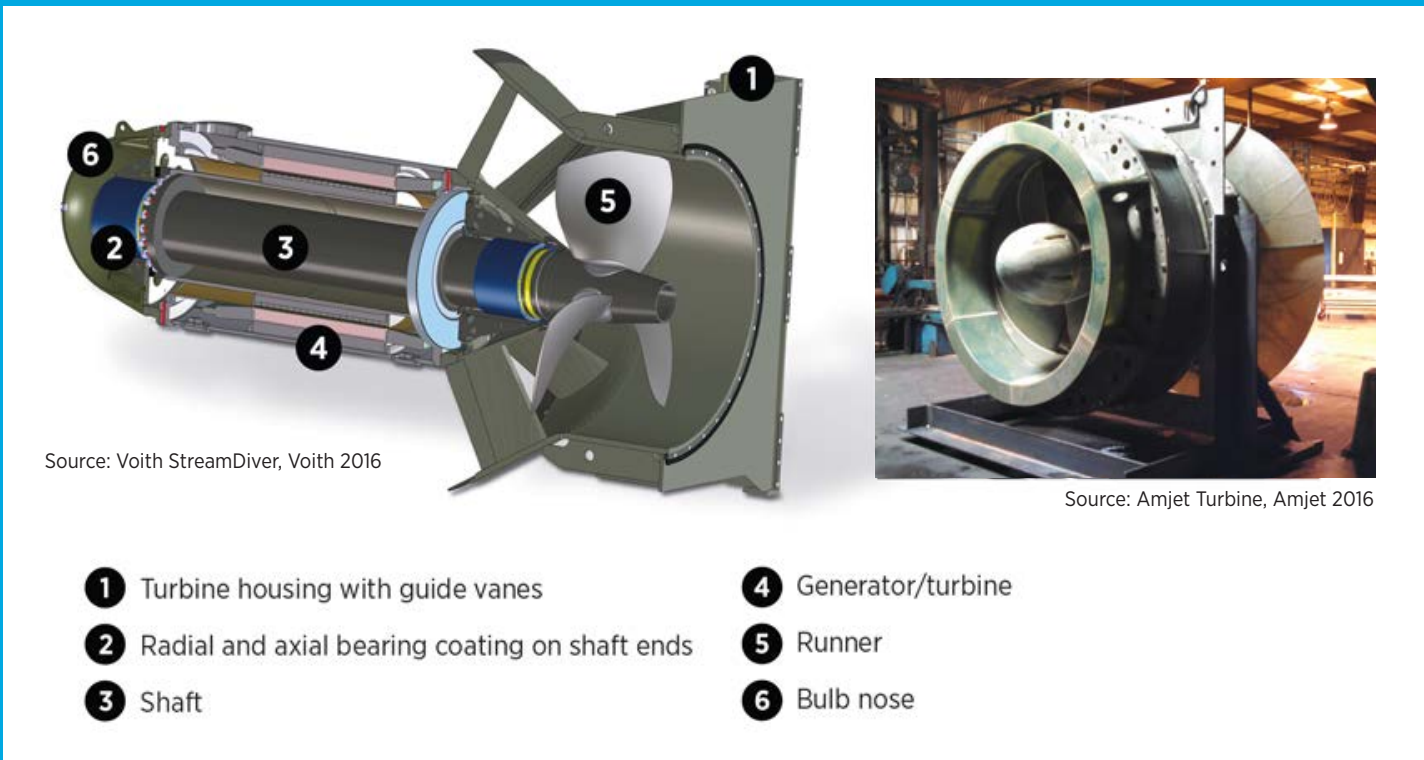

Figure ES-11. Examples of compact, integrated generator/turbine designs 


\section{ES.4 Results: Overall Positive Benefit to the Nation}

The existing hydropower (hydropower generation and pumped storage) fleet, and new deployment as modeled in the Advanced Technology, Low Cost Finance, Combined Environmental Considerations scenario provide significant economic and social benefits: $\$ \mathbf{2 0 9}$ billion savings from avoided global damages from GHG emissions; 6,700-16,200 premature deaths avoided with $\$ 58$ billion savings in avoided mortality, morbidity, and economic damages from cumulative reduction in emissions of $\mathrm{SO}_{2}, \mathrm{NO}_{\mathrm{x}}$ and $\mathrm{PM}_{2.5}$; and 30 trillion gallons of avoided water withdrawals between 2017 and 2050. Additionally, more than 195,000 jobs are supported in 2050 (Figure ES-12).

Benefits-Existing and New Capacity, 2017-2050,a,b,c

\begin{tabular}{|c|c|c|c|c|c|}
\hline & $\begin{array}{l}\text { Economic } \\
\text { Investment }\end{array}$ & $\begin{array}{c}\text { GHG } \\
\text { Greenhouse } \\
\text { Gases }\end{array}$ & $\begin{array}{c}\text { Air } \\
\text { Pollution } \\
\text { Air } \\
\text { Pollution }\end{array}$ & Water & Jobs \\
\hline $\begin{array}{l}\text { Existing } \\
\text { Fleet } \\
\text { and New } \\
\text { Capacity } \\
\text { Additions } \\
\text { Combined } \\
\text { (149.5 GW) }\end{array}$ & $\begin{array}{l}\$ 148 \text { billion in } \\
\text { cumulative eco- } \\
\text { nomic investment }^{\text {d }} \\
\$ 110 \text { billion for } \\
\text { hydropower gen- } \\
\text { eration and } \$ 38 \\
\text { billion for } \mathrm{PSH}\end{array}$ & $\begin{array}{l}\text { Cumulative } \mathrm{GHG} \\
\text { emissions reduced } \\
\text { by } 5,600,000,000 \\
\text { metric tons } \mathrm{CO}_{2}- \\
\text { equivalent, saving } \\
\$ 209 \text { billion in } \\
\text { avoided global } \\
\text { damages }\end{array}$ & $\begin{array}{l}\$ 58 \text { billion savings in avoided } \\
\text { mortality, morbidity, and } \\
\text { economic damages from } \\
\text { cumulative reduction in emis- } \\
\text { sions of } \mathrm{SO}_{2}, \mathrm{NO}_{x} \text {, and } \mathrm{PM}_{2.5} \\
6,700-16,200 \text { premature } \\
\text { deaths avoided }\end{array}$ & $\begin{array}{l}\text { Cumulative } 30 \\
\text { trillion gallons } \\
\text { of water with- } \\
\text { drawals avoided } \\
\text { for the electric } \\
\text { power sector }\end{array}$ & $\begin{array}{l}\text { Over } 195,000 \\
\text { hydropower- } \\
\text { related gross } \\
\text { jobs spread } \\
\text { across the } \\
\text { nation in } 2050\end{array}$ \\
\hline
\end{tabular}

Figure ES-12. Selected benefits and impacts from the existing hydropower fleet and from new deployment, 2017-2050

a. Cumulative benefits are reported on a Net Present Value basis (\$2015) for the period of 2017 through 2050.

b. Estimates reported reflect central values within a range of estimates as compared to the baseline scenario with no new hydropower.

c. Existing fleet includes new projects and plant retirements announced as of the end of 2015; new development reflects the modeled scenario titled Advanced Technology, Low Cost Finance, and Combined Environmental Considerations.

d. Capital investment and annual operating expenses, 2017-2050.

Benefits-Existing Capacity, 2017-2050 a,b,c

\begin{tabular}{|c|c|c|c|c|c|}
\hline & $\begin{array}{l}\text { Economic } \\
\text { Investment }\end{array}$ & $\begin{array}{l}\text { GHG } \\
\text { Greenhouse } \\
\text { Gases }\end{array}$ & $\begin{array}{l}\text { Pollution } \\
\text { Air } \\
\text { Pollution }\end{array}$ & Water & Jobs \\
\hline $\begin{array}{l}\text { Existing } \\
\text { Fleet } \\
(101.2 \mathrm{GW})\end{array}$ & $\begin{array}{l}\$ 77 \text { billion in } \\
\text { cumulative eco- } \\
\text { nomic investment }^{d}\end{array}$ & $\begin{array}{l}\text { Cumulative } \mathrm{GHG} \\
\text { emissions reduced } \\
\text { by } 4,900,000,000 \\
\text { metric tons } \mathrm{CO}_{2}^{-} \\
\text {equivalent, } \$ 184.5 \\
\text { billion savings }\end{array}$ & $\begin{array}{l}\$ 58 \text { Billion savings in avoided } \\
\text { mortality, morbidity, and } \\
\text { economic damages from } \\
\text { cumulative reduction in emis- } \\
\text { sions of } \mathrm{SO}_{2}, \mathrm{NO}_{x} \text {, and } \mathrm{PM}_{2.5}\end{array}$ & $\begin{array}{l}\text { Cumulative } 30 \\
\text { trillion gallons } \\
\text { of water with- } \\
\text { drawals avoided } \\
\text { for the electric } \\
\text { power sector }\end{array}$ & $\begin{array}{l}120,500 \\
\text { hydropower- } \\
\text { related gross } \\
\text { jobs spread } \\
\text { across the } \\
\text { nation in } 2050\end{array}$ \\
\hline
\end{tabular}

Figure ES-13. Selected cumulative benefits and impacts from the existing hydropower fleet, 2017-2050

\footnotetext{
a. Cumulative benefits are reported on a Net Present Value basis (\$2015) for the period of 2017 through 2050.

b. Estimates reported central values within a range of estimates as compared to the baseline scenario with no new hydropower.

c. Existing fleet includes new projects and plant retirements announced as of the end of 2015.

d. Capital investment and annual operating expenses, 2017-2050.
} 
To estimate selected impacts, costs, and benefits for both the existing hydropower fleet and for new hydropower capacity deployment, the Advanced Technology, Low Cost Finance, Combined Environmental Considerations scenario was compared to a baseline scenario under which no new unannounced (as of 2016) hydropower is built.

\section{ES.4.1 Impacts: Existing Fleet}

The Hydropower Vision analysis found that cumulative GHG and air pollution impacts of the existing hydropower fleet between 2017 and 2050 total \$185 billion in savings from avoided global damages from power sector GHG emissions and $\$ 58$ billion in savings from avoided mortality, morbidity, and economic damages from cumulative reduction in emissions of $\mathrm{SO}_{2}, \mathrm{NO}_{x}$, and $\mathrm{PM}_{2.5}$ (see Figure ES-13), as compared to a baseline of no new unannounced hydropower.

\section{ES.4.2 Impacts: New Capacity Additions}

The cumulative impacts from avoided power sector GHG emissions from new hydropower capacity additions between 2017 and 2050 total nearly $\$ 25$ billion in savings from avoided global damages (Figure ES-14 and Table ES-4) as compared to Business-as-Usual.

Benefits-New Capacity, 2017-2050 a,b,c

\begin{tabular}{|c|c|c|c|c|c|}
\hline & $\begin{array}{l}\text { Economic } \\
\text { Investment }\end{array}$ & $\begin{array}{c}\text { GHG } \\
\text { Greenhouse } \\
\text { Gases }\end{array}$ & $\begin{array}{c}\text { Air } \\
\text { Pollution } \\
\text { Air } \\
\text { Pollution }\end{array}$ & $\mathrm{H}_{2} \mathrm{O}$ & Jobs \\
\hline $\begin{array}{l}\text { New Capacity } \\
\text { Additions } \\
\text { (48.3 GW) }\end{array}$ & $\begin{array}{l}\$ 71 \text { billion in cumu- } \\
\text { lative economic } \\
\text { investment }^{d}\end{array}$ & $\begin{array}{l}\text { Cumulative } \mathrm{GHG} \\
\text { emissions reduced } \\
\text { by } 700,000,000 \\
\text { metric tons } \mathrm{CO}_{2}- \\
\text { equivalent, } \$ 24.5 \\
\text { Billion savings }\end{array}$ & $\mathrm{n} / \mathrm{a}^{\mathrm{e}}$ & $\mathrm{n} / \mathrm{a}^{f}$ & $\begin{array}{l}76,000 \text { hydropower- } \\
\text { related gross jobs } \\
\text { spread across the } \\
\text { nation in } 2050\end{array}$ \\
\hline
\end{tabular}

Figure ES-14. Selected benefits and impacts from new hydropower capacity additions under the Advanced Technology, Low Cost Finance, Combined Environmental Considerations scenario, 2017-2050

a. Cumulative benefits are reported on a Net Present Value basis (\$2015) for the period of 2017 through 2050.

b. Estimates reported reflect central values within a range of estimates as compared to the baseline scenario with no new hydropower.

c. Existing fleet includes new projects and plant retirements announced as of the end of 2015; new development reflects the modeled scenario titled Advanced Technology, Low Cost Finance, and Combined Environmental Considerations.

d. Capital investment and annual operating expenses, 2017-2050

e. In the model, once the Clean Power Plan carbon cap is realized, the addition of new hydropower can displace marginal natural gas generation, thereby allowing for additional coal generation-and associated criteria pollutant emissions which reduced the calculated value of avoided air pollution emissions for new hydropower deployment by $\$ 6.2$ billion over the 2017-2050 time period. However, this result reflects the model's use of AEO 2015 Reference Case natural gas prices, which are higher than those in the more recent AEO 2016 Reference Case. AEO 2016 data were unavailable for inclusion in the Hydropower Vision analysis, but lower natural gas prices could allow new hydropower to displace more coal relative to natural gas. Due to the sensitivity of this result to recently updated natural gas price projections, the $\$ 6.2$ billion reduction in value is not reflected in the total value of avoided $\mathrm{SO}_{2}, \mathrm{NO}_{x}$, and $\mathrm{PM}_{25}$ in the Advanced Technology, Low Cost Finance, and Combined Environmental Considerations scenario.

f. Cumulative 2017-2050 water use impacts from new hydropower capacity in the Advanced Technology, Low Cost Finance, Combined Environmental Considerations scenario include a $0.1 \%$ increase in water withdrawals ( 0.8 trillion gallons). Given the magnitude of these impacts relative to those from the existing fleet and model precision limitations generally, these results are not reflected in the avoided water use impacts reported here. 
Table ES-4: Cumulative Impacts ${ }^{\mathrm{a}}$ of Hydropower under the Advanced Technology, Low Cost Finance, Combined Environmental Considerations Scenario, 2017-2050

\begin{tabular}{|c|c|c|c|c|c|}
\hline $\begin{array}{l}\text { Resource } \\
\text { Category }\end{array}$ & $\begin{array}{l}\text { Capacity, } \\
2050 \text { (GW) }\end{array}$ & $\begin{array}{l}\text { Avoided GHG } \\
\text { Emissions } \\
\text { (\$B) }\end{array}$ & $\begin{array}{l}\text { Avoided Emissions } \\
\text { of } \mathrm{SO}_{2}, \mathrm{NO}_{\mathrm{x}} \text {, and } \\
\mathrm{PM}_{2.5}(\$ \mathrm{~B})^{\mathrm{b}}\end{array}$ & $\begin{array}{l}\text { Avoided Water } \\
\text { Use (trillion } \\
\text { gallons) }\end{array}$ & $\begin{array}{l}\text { Annual Jobs } \\
\text { Supported, } \\
2050\end{array}$ \\
\hline $\begin{array}{l}\text { Existing } \\
\text { Hydropower }\end{array}$ & 101.2 & 184.6 & 57.8 & $\begin{array}{l}30.1 \text { withdrawn, } \\
2.2 \text { consumed }\end{array}$ & 120,500 \\
\hline New Hydropower & 48.3 & 24.5 & $n / a^{d}$ & $n / a^{e}$ & 76,000 \\
\hline Total & 149.5 & 209 & 57.8 & $\begin{array}{l}30.1 \text { withdrawn, } \\
2.2 \text { consumed }\end{array}$ & 196,500 \\
\hline
\end{tabular}

a. As compared to a baseline scenario, under which no new unannounced (as of 2016) hydropower is built.

b. Savings in avoided mortality, morbidity, and economic damages.

c. Water withdrawal is water that is removed from the ground or diverted from a water source for use, but then returned to that source, Water consumption is water that is removed from the immediate water environment altogether, e.g., through evaporation or use for production and crops.

d. The Clean Power Plan (CPP)-which is estimated to provide substantial air quality benefits -limits total carbon emissions but does not directly limit $\mathrm{SO}_{2}, \mathrm{NO}_{x}$, and $\mathrm{PM}_{2.5}$ emissions. In the model, once the CPP carbon cap is realized, the addition of new hydropower can displace marginal natural gas generation, thereby allowing for additional coal generation-and associated criteria pollutant emissions which reduced the calculated value of avoided air pollution emissions for new hydropower deployment by $\$ 6.2$ billion and avoided water withdrawals by 0.8 trillion gallons over the 2017-2050 time period. However, this result reflects the model's use of AEO 2015 Reference Case natural gas prices, which are higher than those in the more recent AEO 2016 Reference Case. AEO 2016 data were unavailable for inclusion in the Hydropower Vision analysis, but lower natural gas prices could allow new hydropower to displace more coal relative to natural gas. Due to the sensitivity of this result to recently updated natural gas price projections, the $\$ 6.2$ billion reduction in value is not reflected in the total value of avoided $\mathrm{SO}_{2}, \mathrm{NO}_{\mathrm{x}}$ and $\mathrm{PM}_{2.5}$ and the 0.8 trillion gallon reduction is not reflected in the avoided water withdrawals total in the Advanced Technology, Low-Cost Finance, and Combined Environmental Considerations scenario.

e. Cumulative 2017-2050 water use impacts from new hydropower capacity in the Advanced Technology, Low-Cost Finance, Combined Environmental Considerations scenario include a $0.1 \%$ increase in water withdrawals ( 0.8 trillion gallons) and a $0.0 \%$ change in water consumption ( 0.00 trillion gallons). Given the magnitude of these impacts relative to those from the existing fleet and model precision limitations generally, these results are also not reflected in the avoided water use impacts reported here; they are however, summarized in the main body of Chapter 3.

f. EPA (Environmental Protection Agency). 2015. Carbon Pollution Emission Guidelines for Existing Stationary Sources: Electric Utility Generating Units. Washington, D.C.: Environmental Protection Agency. Accessed July 6, 2016. https://www.federalregister.gov/articles/2014/06/18/201413726/carbon-pollution-emission-guidelines-for-existing-stationary-sources-electric-utility-generating.

\section{ES.4.3 Impacts: Combined Existing Fleet and New Capacity Deployment}

The overall impacts to human health through reduction of air pollution from the combined capacity of existing and new hydropower were calculated through 2050 (Chapter 3) for avoided fossil-fueled power plant emissions to comprise 330,000 metric tonnes of $\mathrm{PM}_{2.5}, 2,760,000$ metric tonnes of $\mathrm{NO}_{x}$, and $1,640,000$ metric tonnes of $\mathrm{SO}_{2}$. These reductions could result in avoidance of 6,700-16,200 premature deaths. Cumulative capital and operating expenditures from 2017 to 2050 are approximately $\$ 110$ billion for hydropower generation and $\$ 38$ billion for $\mathrm{PSH}$.

\section{Key modeling takeaways:}

1. Across the breadth of scenarios, new hydropower capacity could add several billion dollars in societal value in the form of avoided GHG and air pollution emissions, avoided water consumption, and avoided water withdrawals;

2. Investments in the hydropower industry are expected to be on the order of $\$ 4.2$ billion per year under Business as Usual, and $\$ 9.9$ billion per year under the Advanced Technology, Low Cost Finance, Combined Environmental Considerations scenario; and

3. The existing fleet will continue to contribute a substantial majority of the societal benefits of hydropower as a whole. 
The Hydropower Vision roadmap was developed through extensive collaboration, contributions, and rigorous peer review from industry, the electric power sector, non-governmental organizations, academia, national laboratories, and representatives of government agencies. The roadmap (Chapter 4) outlines, in a non-prescriptive manner, potential actions for consideration by all stakeholder sectors to address many of the challenges that have affected hydropower (hydropower generation and pumped storage) in recent decades. These roadmap actions are intended to leverage the existing hydropower fleet and potential for sustainable hydropower growth to increase and support the nation's renewable energy portfolio, economic development, environmental stewardship, and effective use of resources through specific technical, environmental, economic, and institutional stakeholder actions. It is beyond the scope and purview of the Hydropower Vision to suggest policy preferences or recommendations, and no attempt is made to do so.

The roadmap actions are based on the three foundational "pillars" of the Hydropower Visionhydropower optimization, growth, and sustainability. The intended results of the roadmap actions, as aligned to these foundational pillars, are:

- Optimization: Investment in technology advancement, modernization, and environmental performance to ensure that the existing wide range of high-value, multi-use benefits of the hydropower fleet do not diminish.

- Growth: Development of the next generation of hydropower facilities, and a trained workforce to support them, that leverage untapped infrastructure, technology advancement, plant modernization, improved environmental performance, and cost reduction pathways.

- Sustainability: Ensure that environmental objectives are incorporated throughout the full hydropower facility life cycle.

Within the five topical areas listed, the roadmap identifies 21 sub-categories and 64 actions. The Hydropower Vision roadmap strategic approach is summarized in Table ES-5 and high-level Hydropower Vision roadmap actions are summarized in Table ES-6. The defined roadmap action areas are:

1. Technology Advancement: Innovative technology and system design concepts will be essential to attaining the necessary outcomes of cost reduction, improved performance, and environmental stewardship. These include advances such as standardized powertrain components, biologically-based equipment design and evaluation, additive manufacturing, modular civil structure design, and alternative closed-loop PSH systems. Technical progress will require demonstration of environmental mitigation technologies for facilities of all sizes and performance testing and validation of hydropower innovations. New technologies will need to accommodate demands for greater operational flexibility with growing integration of variable generation resources into the electric grid.

2. Sustainable Development and Operation: An integrated approach to hydropower project development that incorporates environmental objectives, metrics, and methodologies is required to balance environmental, social, and economic factors in a future in which climate change may influence water resources and ecosystem health. Extensive stakeholder collaboration will be necessary to address interactions of individual hydropower projects with other hydropower projects and water uses within and among basins or watersheds to achieve optimum delivery of power and non-power benefits. Reservoir operations and other basin/watershed factors or competing uses and demands should be evaluated during planning processes to ensure that new development is compatible with and supports multiple objectives under changing energy demands and hydrologic conditions over time.

3. Enhanced Revenue and Market Structures: Improved market structures and compensation mechanisms could more appropriately incentivize new and existing hydropower for the numerous services and benefits it provides, including energy production, capacity, ancillary grid support 
services, operational flexibility, energy storage, and other essential grid reliability services. Important actions in this area include determining how much flexibility is provided by hydropower in existing grid operations, exploring opportunities to enhance market valuation of that flexibility, and examining how and on what time scale settlement of prices in energy markets could facilitate better utilization of hydropower flexibility to support integration of variable renewable generation resources.

\section{Regulatory Process Optimization: While the} approval and compliance processes administered by various authorities provide a consistent framework to assess potential impact and develop and implement mitigation measures to minimize and avoid those impacts, they also result in uncertainty in field study and administrative costs, and implementation schedules that can render it challenging to undertake, finance, and complete projects. Regulatory process enhancements that reduce implementation timeframes may be possible through process efficiency improvements and by providing stakeholders with an increased knowledge base, easier access to information, and increased capabilities for collaboration. Achieving outcomes more quickly and predictably may reduce the risks and costs to the developer without a reduction in environmental protection. Actions in this topical area include, but are not limited to, assessment of science and technology innovations affecting environmental impact or mitigation.

\section{Enhanced Collaboration, Education, and Out-}

reach: The awareness of hydropower's benefits as well as its impacts can be increased through development and dissemination of objective and verified information. Hydropower facility owners and developers could benefit from an ongoing national-scale effort to identify and regularly update benchmarks and best practices for maintaining, operating, and constructing hydropower facilities, as well as by performing retrospective operational performance studies. In order to maintain and grow the industry, the nation could sustain and expand its highly qualified and welltrained workforce by developing hydropower-specific curricula for vocational and university programs to motivate, prepare, and provide training opportunities for new professionals to enter the hydropower field.

\section{Key findings from the roadmap include:}

1. The hydropower industry and research community will need to take an innovative approach to designing a suite of technologies and civil structures that can successfully balance multiple objectives, including cost-effective energy production, penetration of variable renewable generation resources, water management, and environmental protection;

2. Collaboration is critical across all roadmap action areas, whether it's within the industry to develop the next generation of technologies; amongst stakeholders to better improve the regulatory process; or between industry and academia to prepare the incoming workforce;

3. Improving the environmental performance of hydropower technologies can help achieve environmental objectives. Developing a comprehensive set of science-based environmental performance metrics and assessment tools will further the design and sustainable operation of hydropower projects;

4. Undertaking actions such as establishing better mechanisms for collaboration and disseminating successful practices can improve regulatory process implementation; and

5. Outreach actions cut across all roadmap areas. Articulating and disseminating objective information regarding hydropower's role as an established and cost-effective renewable energy source, its importance to grid stability and reliability, and its ability to support variable generation can help increase hydropower's acceptance and lead to: (a) increased investor confidence; (b) improved understanding among stakeholders of environmental, social, and regulatory objectives; (c) improved compensation for grid services; and (d) enhanced eligibility in renewable and clean energy markets.

While the roadmap includes collective steps that can be taken by many parties working in concert, it cannot and does not represent federal agency obligations or commitments. 
Table ES-5. Hydropower Vision Roadmap Strategic Approach

\begin{tabular}{|c|c|c|c|}
\hline $\begin{array}{c}\text { Core } \\
\text { Challenge }\end{array}$ & $\begin{array}{l}\text { Facilitate and leverage } \\
\text { growth to increase and s } \\
\text { development, envir }\end{array}$ & $\begin{array}{l}\text { e existing hydropower fleet anc } \\
\text { pport the nation's renewable er } \\
\text { nmental stewardship, and effec }\end{array}$ & $\begin{array}{l}\text { sustainable hydropower } \\
\text { ergy portfolio, economic } \\
\text { ive use of resources. }\end{array}$ \\
\hline $\begin{array}{l}\text { Key } \\
\text { Objectives }\end{array}$ & $\begin{array}{l}\text { Optimization } \\
\text { Advance the nation's hydro- } \\
\text { power fleet by maintaining its } \\
\text { long-standing economic value, } \\
\text { energy contribution, and crit- } \\
\text { ical water management infra- } \\
\text { structure, while modernizing } \\
\text { and optimizing its facilities, } \\
\text { operations, and environmental } \\
\text { performance. }\end{array}$ & $\begin{array}{l}\text { Growth } \\
\text { Expand hydropower through } \\
\text { innovative technologies, } \\
\text { utilization of existing infra- } \\
\text { structure, enhanced value } \\
\text { recognition in electricity and } \\
\text { environmental markets, and } \\
\text { improved efficiency in regula- } \\
\text { tory processes. }\end{array}$ & $\begin{array}{l}\text { Sustainability } \\
\text { Maintain the overall value of } \\
\text { hydropower to the nation } \\
\text { through balancing economic, } \\
\text { social, and energy-related } \\
\text { factors with the co-objective } \\
\text { of responsible environmental } \\
\text { stewardship. }\end{array}$ \\
\hline $\begin{array}{l}\text { Intended } \\
\text { Results }\end{array}$ & $\begin{array}{l}\text { Investment in technology } \\
\text { advancement, moderniza- } \\
\text { tion, and environmental } \\
\text { performance to ensure that } \\
\text { the existing wide range of } \\
\text { high-value, multi-use benefits } \\
\text { of the hydropower fleet do not } \\
\text { diminish. }\end{array}$ & $\begin{array}{l}\text { Development of the next gen- } \\
\text { eration of hydropower facili- } \\
\text { ties-and a trained workforce } \\
\text { to support them-that lever- } \\
\text { age untapped infrastructure, } \\
\text { technology advancement, } \\
\text { plant modernization, improved } \\
\text { environmental performance, } \\
\text { and cost reduction pathways. }\end{array}$ & $\begin{array}{l}\text { Capture and increase of the } \\
\text { enduring economic and social } \\
\text { value of hydropower through } \\
\text { reduction of environmental } \\
\text { impacts and continuous im- } \\
\text { provement of power systems } \\
\text { and other project resources } \\
\text { to ensure that sustainability } \\
\text { objectives are incorporated } \\
\text { throughout the full hydropower } \\
\text { facility life cycle. }\end{array}$ \\
\hline $\begin{array}{l}\text { Linkage to } \\
\text { Hydropower } \\
\text { Vision }\end{array}$ & \multicolumn{3}{|c|}{$\begin{array}{l}\text { The modeling within the Hydropower Vision presents potential hydropower development } \\
\text { scenarios based on varying assumptions about key factors influencing growth over a 35-year } \\
\text { period and beyond. Activities undertaken within the five Action Areas listed below are designed } \\
\text { to incorporate the Core Challenge, Key Objectives, and Intended Results, and can significantly } \\
\text { affect which of those development scenarios will ultimately be realized. }\end{array}$} \\
\hline $\begin{array}{l}\text { Roadmap } \\
\text { Action } \\
\text { Areas }\end{array}$ & \multicolumn{3}{|c|}{$\begin{array}{l}\text { 4.1 Technology Advancement } \\
\text { 4.2 Sustainable Development and Operation } \\
\text { 4.3 Enhanced Revenue and Market Structures } \\
\text { 4.4 Optimizing Regulatory Process Optimization } \\
\text { 4.5 Enhanced Collaboration, Education, and Outreach } \\
\text { Roadmap Action Areas are numbered " } 4 . x \text { " in order to correspond with Chapter } 4 \text { of the Hydropower Vision report. }\end{array}$} \\
\hline $\begin{array}{l}\text { Sectors of } \\
\text { Potential } \\
\text { Growth }\end{array}$ & \multicolumn{3}{|c|}{$\begin{array}{l}\text { - Upgrades to existing hydropower facilities (Upgrades) } \\
\text { - Powering of existing non-powered dams (NPD) } \\
\text { - Installations in existing water conveyance infrastructure (Conduits) } \\
\text { - Pumped storage hydropower (PSH) } \\
\text { - New stream-reach development (NSD) } \\
\text { Each action in the roadmap indicates the specific growth sector(s) to which it applies. }\end{array}$} \\
\hline
\end{tabular}


Table ES-6. High-Level Hydropower Vision Roadmap Actions

(Roadmap Action Areas are numbered "4.x" in order to correspond with Chapter 4 of the Hydropower Vision report.)

\subsection{Technology Advancement}

\section{Action 4.1.1-Develop Next-Generation Hydropower Technologies}

The next generation of hydropower and PSH technologies must be able to realize high efficiencies and enhanced performance, while minimizing environmental footprint and lowering capital costs.

\section{Action 4.1.2-Enhance Environmental Performance of New and Existing Hydropower Technologies}

Environmental performance (e.g., fish survival rates, water quality) of hydropower and PSH technologies is a significant concern of all parties and should thus be evaluated and, when necessary, modified to ensure continual improvement.

Action 4.1.3-Validate Performance and Reliability of New Hydropower and PSH Technologies

Validating performance of new hydropower and PSH technologies can increase investor confidence, thereby facilitating greater deployment of new capacity.

\section{Action 4.1.4-Ensure Hydropower Technology Can Support Increased Use of Variable Renewable} Generation Resources

Technology innovation can minimize increased wear and tear on hydropower and PSH machinery that results from increased penetrations of variable renewable generation resources, such as wind and solar, in power systems.

\subsection{Sustainable Development and Operation}

\section{Action 4.2.1-Increase Hydropower's Resilience to Climate Change}

Providing frameworks for assessing climate change impacts can improve the ability of hydropower projects to operate under resultant increases in variability (e.g., temporal and spatial changes in water availability or water use).

\section{Action 4.2.2-Improve Coordination among Hydropower Stakeholders}

Improved coordination and collaboration among hydropower stakeholders can facilitate better realization of multiple objectives (e.g., social, environmental, electricity generation) through hydropower development planning.

\section{Action 4.2.3-Improve Integration of Water Use within Basins and Watersheds}

The development of innovative tools and approaches can increase opportunities for better integration of multiple water uses and objectives.

\section{Action 4.2.4-Evaluate Environmental Sustainability of New Hydropower Facilities}

Developing quantifiable environmental sustainability metrics and applying them to the development and operation of new hydropower facilities can lead to greater consistency in permitting processes and qualification for national, state, and local renewable energy goals.

\subsection{Enhanced Revenue and Market Structures}

Action 4.3.1-Improve Valuation and Compensation of Hydropower in Electricity Markets

Enhancing existing market approaches and developing new approaches can help facilitate full recognition and compensation of the suite of grid services, operational flexibility, and system-wide benefits offered by new and existing hydropower.

\section{Action 4.3.2-Improve Valuation and Compensation of PSH in Electricity Markets}

Enhanced market rules related to scheduling and operation of PSH in electricity markets can facilitate use of the full value of this energy storage technology. 


\section{Action 4.3.3-Remove Barriers to the Financing of Hydropower Projects}

The economics of developing new hydropower projects can be improved by facilitating access to low-cost capital and investors with long-term perspective.

Action 4.3.4-Improve Understanding of and Eligibility/Participation in Renewable and Clean Energy Markets. Creating a set of tools to better understand policy rules and market eligibility can help reduce confusion and point developers towards the highest value markets for which their hydropower projects are eligible.

\subsection{Regulatory Process Optimization}

\section{Action 4.4.1-Provide Insights into Achieving Improved Regulatory Outcomes}

Identifying and disseminating best practices can help lead to successful energy, environment-related, and socioeconomic outcomes of the hydropower regulatory process.

\section{Action 4.4.2-Accelerate Stakeholder Access to New Science and Innovation for Achieving} Regulatory Objectives

Improving the ability of stakeholders to use new science and innovation can enhance environmental outcomes; increase the value of hydropower facilities; and reduce costs of permitting, licensing, and compliance.

\section{Action 4.4.3-Analyze Policy Impact Scenarios}

Improving the ability to assess potential impacts of policy options on markets, power systems, ecosystems, and populations-all on local, regional, and national scales-can inform decision makers.

Action 4.4.4-Enhance Stakeholder Engagement and Understanding within the Regulatory Domain Activities under this action will ensure all stakeholders have access to the knowledge and experience necessary to participate effectively in planning, decision making, and regulatory processes.

4.5 Enhanced Collaboration, Education, and Outreach

Action 4.5.1-Increase Acceptance of Hydropower as a Renewable Energy Source Demonstrating and communicating that hydropower is a core renewable energy source can both increase public understanding and encourage inclusion of hydropower in clean energy planning and markets, as appropriate.

Action 4.5.2-Compile, Disseminate, and Implement Best Practices and Benchmarking in Operations and Research and Development

Compiling and disseminating methods and best practices from leading performers in all segments of the hydropower industry can drive improvements in hydropower performance.

Action 4.5.3-Develop and Promote Professional and Trade-Level Training and Education Programs Evaluating and developing comprehensive training and education programs, with engagement from high school to university and trade school levels, can help encourage and anticipate the technical and advanceddegree workforce required to meet the industry's long-term needs.

Action 4.5.4-Leverage Existing Research and Analysis of the Federal Fleet in Investment Decisions Extensive research data about the federal hydropower fleet exist and should be made available in compiled form to be used by policymakers and agency staff in making federal investment decisions.

Action 4.5.5-Maintain the Roadmap in Order to Achieve the Objectives of the Hydropower Vision The Hydropower Vision roadmap should be regularly updated by tracking hydropower technology advancement and deployment progress, and prioritizing research and development activities. 
One of the greatest challenges for the United States in the 21st century is producing and making available clean, affordable, and secure energy. Hydropower (hydropower generation and pumped storage) has been and can continue to be a substantial part of addressing that challenge. Although the hydropower industry has adopted improved technology and exhibited significant growth over the past century, the path that led to its historical growth rates is different today, and continued evolution of that path-including transformative innovation-is needed.

The Hydropower Vision report highlights the national opportunity to capture additional domestic lowcarbon renewable energy with responsible development of advanced hydropower technologies across all U.S. market sectors and regions. Where objectively possible, the analysis quantifies the associated costs and benefits of this deployment and provides a roadmap for the collaboration needed for successful implementation.

\section{ES.6.1 The Opportunity}

The Hydropower Vision analysis modeled a future scenario combining Advanced Technology, Low Cost Finance, and Combined Environmental Considerations, finding that U.S. hydropower could grow from $101 \mathrm{GW}$ of combined generating and storage capacity in 2015 to nearly 150 GW by 2050, realizing over $\mathbf{5 0 \%}$ of this growth by $\mathbf{2 0 3 0}$. Growth under this modeled scenario would result from a combination of $13 \mathrm{GW}$ of new hydropower generation capacity (upgrades to existing plants, adding power at existing dams and canals, and limited development of new stream-reaches), and $36 \mathrm{GW}$ of new pumped storage capacity. Additional NSD above this scenario could conceivably become economically viable in the future if significant and transformative innovation were achieved that could address a range of environmental considerations. Increasing hydropower can simultaneously deliver an array of benefits to the nation that address issues of national concern, including climate change, air quality, public health, economic development, energy diversity, and water security. For example, the 5.6 gigatonnes of carbon dioxide equivalent ${ }^{16}$ avoided over the period 20172050 delivers $\$ 209$ billion in savings for avoided global damages. Based on the cost quantifications of the Hydropower Vision, the value of these types of long-term social benefits can be provided by hydropower and exceed the initial industry investment. Additionally, new PSH technology can further facilitate integration of variable generation resources such as wind and solar into the national power grid due to its ability to provide grid flexibility, reserve capacity, and system inertia.

\section{ES.6.2 The Risks of Inaction}

While the industry is mature, many actions and efforts remain critical to further advancement of domestic hydropower as a key energy source of the future. This includes continued technology development to increase efficiency, advance sustainability, and drive down costs, as well as the availability of market mechanisms that take into account the value of grid reliability services, air quality and reduced emissions, and long asset lifetimes. The lack of well-informed, coordinated actions to meet these challenges reduces the likelihood that potential benefits to the nation will be realized. Failure to address business risks associated with hydropower development costs and development timelines-including uncertainties related to negotiation of interconnect

16. Carbon dioxide equivalent is a measure used to compare the emissions from various greenhouse gases based upon their global warming potential. "Glossary of Statistical Terms, Carbon Dioxide Equivalent." Last updated April 4, 2013. Organisation for Economic Co-operation and Development. Accessed July 7, 2016. https://stats.oecd.org/glossary/detail.asp?/D=285. 
fees and power sales contracts, regulatory process inefficiencies, environmental compliance, financing terms, and revenue sources- could mean that opportunities for new deployment will not be realized. Engagement with the public, regulators, and other stakeholders is needed to address environmental considerations effectively. Continued research and analysis on energy policy and hydropower costs, benefits, and effects is important to provide accurate information to policymakers and for public discourse. Finally, regularly revisiting the Hydropower Vision roadmap and update priorities across stakeholder groups and disciplines is essential to ensuring coordinated pathways toward a robust and sustainable hydropower future.

\section{ES.6.3 The Way Forward}

The Hydropower Vision roadmap identifies a highlevel portfolio of new and continued actions and collaborations across many fronts to help the nation realize the long-term benefits of hydropower, while protecting the nation's energy, environmental, and economic interests. Stakeholders and other interested parties must take the next steps in refining, expanding, operationalizing, and implementing a credible hydropower future. These steps could be developed in formal working groups or informal collaborations and will be critical in overcoming the challenges, capitalizing on the opportunities, and realizing the national benefits detailed in the Hydropower Vision report. 
This report is being disseminated by the Department of Energy. As such, the document was prepared in compliance with Section 515 of the Treasury and General Government Appropriations Act for Fiscal Year 2001 (Public Law 106-554) and information quality guidelines issued by the Department of Energy. Though this report does not constitute "influential" information, as that term is defined in DOE's information quality guidelines or the Office of Management and Budget's Information Quality Bulletin for Peer Review (Bulletin), as detailed in Appendix K, the report was reviewed both internally and externally prior to publication.

\section{NOTICE}

This report was prepared as an account of work sponsored by an agency of the United States government. Neither the United States government nor any agency thereof, nor any of their employees, makes any warranty, express or implied, or assumes any legal liability or responsibility for the accuracy, completeness, or usefulness of any information, apparatus, product, or process disclosed, or represents that its use would not infringe privately owned rights. Reference herein to any specific commercial product, process, or service by trade name, trademark, manufacturer, or otherwise does not necessarily constitute or imply its endorsement, recommendation, or favoring by the United States government or any agency thereof. The views and opinions of authors expressed herein do not necessarily state or reflect those of the United States government or any agency thereof.

Available electronically at $h t t p: / / w w w . o s t i$. gov/scitech

Available for a processing fee to U.S. Department of Energy and its contractors, in paper, from:

U.S. Department of Energy

Office of Scientific and Technical Information P.O. Box 62

Oak Ridge, TN 37831-0062

phone: 865.576 .8401

fax: 865.576 .5728

email: reports@adonis.osti.gov

Available for sale to the public, in paper, from:

U.S. Department of Commerce

National Technical Information Service

5285 Port Royal Road

Springfield, VA 22161

phone: 800.553 .6847

fax: 703.605 .6900

email: orders@ntis.fedworld.gov online ordering: http://www.ntis.gov/help/ ordermethods.aspx 


\section{A New Chapter for America's $1^{\text {sT }}$ Renewable Electricity Source}

This first-of-its-kind analysis builds on the historical importance of hydropower and establishes a roadmap to usher in a new era of growth in sustainable domestic hydropower. 